\title{
The Franciscan Prayer Elicits Empathic and Cooperative Intentions in Atheists: A Neurocognitive and Phenomenological Enquiry
}

\author{
Roberto E. Mercadillo,2*, Juan Fernandez-Ruiz ${ }^{3}$, Omar Cadena ${ }^{1}$, \\ Emilio Domínguez-Salazar ${ }^{1}$, Erick H. Pasaye ${ }^{4}$ and Javier Velázquez-Moctezuma ${ }^{2}$

\begin{abstract}
${ }^{1}$ Area of Neurosciences, Biology of Reproduction Department, CBS, Universidad Autónoma Metropolitana, Unidad Iztapalapa, Mexico City, Mexico, ${ }^{2}$ Consejo Nacional de Ciencia y Tecnología, Mexico City, Mexico, ${ }^{3}$ School of Medicine, Universidad Nacional Autónoma de México, Mexico City, Mexico, ${ }^{4}$ Magnetic Resonance Imaging Unit, Institute of Neurobiology, Universidad Nacional Autónoma de México, Querétaro, Mexico
\end{abstract}

Religiosity influences the alleviation of troubles through cooperative and empathic attitudes, but these involve a sense of community offered in non-religious support

OPEN ACCESS

Edited by:

Susanne Huber,

University of Vienna, Austria

Reviewed by:

Stephen Turner,

University of South Florida,

United States

Hexuan Liu,

University of North Carolina at

Chapel Hill, United States

${ }^{*}$ Correspondence:

Roberto E. Mercadillo emmanuele.mercadillo@ gmail.com

Specialty section: This article was submitted to Evolutionary Sociology and

Biosociology,

a section of the journal

Frontiers in Sociology

Received: 22 October 2017 Accepted: 12 December 2017 Published: 22 December 2017

Citation: Mercadillo RE, Fernandez-Ruiz J, Cadena O, Domínguez-Salazar E,

Pasaye EH and VelázquezMoctezuma J (2017) The Franciscan Prayer Elicits Empathic and Cooperative Intentions in Atheists:

A Neurocognitive and Phenomenological Enquiry. Front. Sociol. 2:22.

doi: 10.3389/fsoc.2017.00022 groups and healthcare institutions too, where individual's spiritual well-being is based on responsibility and solidarity. This is the case of the Alcoholic Anonymous program adopted by several care initiatives, which use the Franciscan Prayer as a fundamental text representing a western epistemic meaning-making system to provide guidance for cooperation and empathy. We aimed to identify the effect of the Franciscan Prayer on the neurocognitive function and emotional-social experiences in 20 persons declared as atheist $(M$ age $=22.85 \pm 2.60$ years). Spiritual profiles, acceptance of religion, and dispositional empathy were psychometrically evaluated. Functional images were acquired in a 3 T scanner to identify BOLD signals while reading The Franciscan Prayer, The Lord's Prayer representing a culturally known religious text with no Franciscan elements, and a birthday serenade representing a culturally known non-religious text. Phenomenological interviews were performed to categorize emotional experiences and social situations associated with reading each text. Results show that spiritual well-being and empathic dispositions are not allied with religious beliefs. The reading of The Franciscan Prayer was correlated with activation in primary motor and premotor cortices, parietal primary and integrative areas, and occipital primary and associative cortices. These motor and sensorial functions might be essential for the empathic attitudes expressed in the Franciscan tradition allowing cooperative actions. This is congruent with the participant's experiences of wellness, reciprocity, responsibility, and helping evoked by this prayer. The Lord's Prayer was correlated with activation in prefrontal regions, as well as, in anterior and posterior portions of the cingulate cortex. These activations may imply mnemonic and moral processes that may be needed for conflict valuations based on childhood and cultural memories evoked by the participants. As testimonies indicate, disgust, confusion, or criticisms were associated with the religious property of the text. We conclude that thoughts, emotions, and actions evoked by The Franciscan Prayer are not inclined by its religious quality but by its empathic and cooperative properties, which may allow for self-reflection and social actions needed for support groups.

Keywords: religiosity, atheism, Franciscan prayer, empathy, cooperation, social cognition 


\section{INTRODUCTION}

A number of studies have reported the influence of religiosity on comfort and alleviation when facing physical, mental, or emotional disorders. Particularly, praying and meditation may elicit psychological states that favor the development of attitudes, such as forgiveness and acceptance, which increase perceived well-being and a sense of control over the uncertainty of illness (Koenig, 2009; Vess et al., 2009; Caixeta et al., 2012; Grossoehme et al., 2013; Torges et al., 2013). These so-called spiritual elements are not only related to a belief in God or with the practice of an organized religion but to a satisfaction with one's own life. Thus, they may be considered as adaptive resources when analyzing how people deal with psychological troubles (McConnell et al., 2006; Koenig, 2009; Rivera-Ledesma and Montero-López, 2014).

Further, social and evolutionary analyses have pointed to the possible role that certain moral aspects of religiosity play in facilitating cooperative behaviors to alleviate the suffering of other people (Bulbulia and Schjoedt, 2013). Nevertheless, morality and cooperation entail social-cognitive processes involving theory of mind (ToM), intentionality, and a sense of community all present among atheists, as well as sophisticated interventions among support groups and healthcare institutions (Bering, 2002). These cognitive social processes and contexts may favor existential feelings, allowing for affective relations with other people and with the world (Slaby and Stephan, 2008), and constitute spaces of respect where non-religious points of view can be expressed as transcendental, moral and empathic attitudes linked to an individual's spiritual well-being based on love, responsibility, and solidarity (Norenzayan and Gervais, 2013; Rivera-Ledesma and Montero-López, 2014).

During the last decade, neurocognitive substrates of religiosity have been researched by using neuroimaging, a set of noninvasive techniques to study the function of human brain by using different instruments. One of these techniques is the called event-related potentials (ERP), which uses electroencephalographic instruments to register the bioelectrical brain signals then decoded as waves and obtained from electrodes located in the surface of the head while an individual performs sensorial, motor, or cognitive tasks. A particular ERP's wave is known as the error-related negativity (ERN) signal observed between 50 and $100 \mathrm{~ms}$ after an individual make an error while executing a cognitive task, even if the individual is not aware of the error. A recurrent task used in experimental psychology to evaluate errors is the Stroop task eliciting semantic interferences when an individual has to name a word, such as "blue," "green," or "red," written in a different color; for example, the word "blue" written in red ink. ERN signals have been identified as coming from the anterior cingulate cortex (ACC) when people commit errors while performing the Stroop task. The ACC represents a highly connected brain region, which function is strongly linked to conflict resolution and complex decision-making based on emotions. This brain function is also associated with anxiety or distress caused by the committed error. To investigate motivation and effects of religious beliefs over the reduction of anxiety, ERP protocols while performing conflictive tasks, such as the Stroop task, have been applied to believers. The typical ERN signals have been observed as low in samples of believers and this low signals correlate with their high religious fervor or conviction. So, these results suggest that religious beliefs guard people against distress when facing uncertainty through controlled and automatic neurocognitive processes [wide explanations of these protocols and experiments can be found in Inzlicht et al. (2009), Inzlicht and Tullett (2010), and Inzlicht et al. (2013)]. A wide explanation of the Stroop task can be found in Mercadillo et al. (2012).

Another neuroimaging technique is the functional magnetic resonance imaging (fMRI), which analysis is based on the called blood oxygen level dependent (BOLD) signal. This analysis considers a neurophysiological principle claiming that when an individual performs a cognitive task, such as reading, watching, earing, or thinking, a cascade of neural and metabolic activity is presented in specific brain regions. This metabolic activity implies the increase of the blood flow in those specific brain regions provoking changes in their oxygen levels which modify their magnetic properties; the changes are detected by the magnetic resonance instrument then decoded as statistical differences in the metabolic activity presented along the brain. So, it is assumed that brain regions with different statistically calculated BOLD signals represent the brain function related with the cognitive performance (for extensive explanations of the fMRI principles see Raichle, 2001; Jezzard and Ramsey, 2003). Also, the functional brain connectivity can be evaluated. This connectivity assumes a temporal dependence between neurophysiological events spatially remotes; a statistical dependence between the BOLD signals detected in different brain regions is measured by applying correlational coefficients. So, the functional connectivity analysis allows identify brain regions which functions are related while performing a cognitive task (van den Heuvel and Hulshoff, 2010; Filippi et al., 2013).

Functional magnetic imaging has been used to study morality, because it represents a human social-cognitive process that is presented in non-religious practices. However, morality is so influenced by religious beliefs that some authors propose that brain functions related with moral concern and those related to analytic thinking are in tension (Jack et al., 2016). Along these lines, some fMRI studies have shown that while performing deontological moral judgments Catholic practitioners recruit the precuneus and temporoparietal junction, but activate the dorsolateral prefrontal cortex and temporal poles while performing utilitarian judgments. These differences are not present among nonbelievers, who manifest superior parietal activity for both kinds of moral judgments. These findings may suggest that Catholic practices influence moral judgments through learning to help and care for others (deontological judgment), but inhibit decisions that may damage other people even if this damage represents welfare for others (utilitarian judgment) (Christensen et al., 2014).

Regarding attribution and the self, activation in the insular cortex is reported when believers and nonbelievers judge whether religious statements are true or false, such as "Jesus Christ really performed the miracles attributed to him in the Bible" (Harris et al., 2009). Since insular functions relate to representing internal states, empathy, and experiencing moral 
emotions (Mercadillo and Díaz, 2013; Mutschler et al., 2013; Decety and Cowell, 2014), its participation may involve morality and emotional processes inserted in religiosity. Furthermore, by using functional brain connectivity analysis with religious believers, it is suggested that religiosity may influence ToM and autobiographical memory. This would then attribute humanlike cognition to supernatural agents as seen in the activity of the dorsal medial prefrontal cortex and the inferolateraldorsolateral cortical pathway. In contrast, nonbelievers manifest activity in the ventral medial prefrontal cortex and the right lateral temporal-occipital pathway, thus facilitating imagery and inhibiting ToM when thinking of supernatural agents (Han et al., 2008; Kapogiannis et al., 2014). Additionally, nonbelievers manifest a similar connectivity between the medial PFC and the posterior parietal cortex/precuneus when making judgments about religious and non-religious leaders' attitudes. Interestingly, this connectivity differs when preforming judgments about one's own attitudes. Christian practitioners, on the other hand, manifest similar mPFC-posterior parietal cortex connectivity when making judgments about their own attitudes and Jesus Christ's attitudes (Ge et al., 2009). Since Christianity entails denying the self to highlight the human dependence on Jesus Christ, these results suggest that Christian practices modulate neurocognitive representations of the self by performing a similar semantic when representing the religious leader.

Neurobiological approaches indicate that religious beliefs influence a variety of cognitive processes including motivation, emotion, morality, social cognition, and representation of the self. Nevertheless, most of the studies have been centered on believers (e.g., Beauregard and Paquette, 2006; Schjoedt et al., 2009, 2011) and when nonbelievers are considered they are generally used for comparison but their spiritual elements and experiences are not explored. These perspectives limit the comprehension of how certain religious elements or practices may favor the development of cooperative and empathic attitudes by generating healthy processes in both believers and nonbelievers (Harris et al., 2009).

Although this last premise has been explored with some types of Buddhist meditation (e.g., Desbordes et al., 2012), no references exist related to western Jewish or Christian traditions, which use texts to guide prayer and reflections on spiritual life, well-being, and otherness. Thus, in the present study, we propose using the Franciscan Prayer as a Catholic religious text representing a western epistemic meaning-making system to provide guidance for cooperation and empathy.

Originally found as an anonymous poem in the Catholic French magazine La Clochette in 1912, the later named Franciscan Prayer was translated into English and many other languages during the 1930s. It was widely distributed around western countries by religious practitioners, politicians, and pacifists during and after the Second World War (an extensive investigation about the origins and dissemination of this prayer can be found in Renoux, 2001). This poem (see Table 1) was attributed to Francis of Assisi since it reflects the main principles of the Franciscan Catholic order founded in 1209, which considers mental and physical illness as inseparable expressions of the individual's spiritual condition (Puchalska-Dabrowska, 2006).
TABLE 1 | The three texts used as reading conditions in the Spanish version as commonly known in Mexico and their English translation.

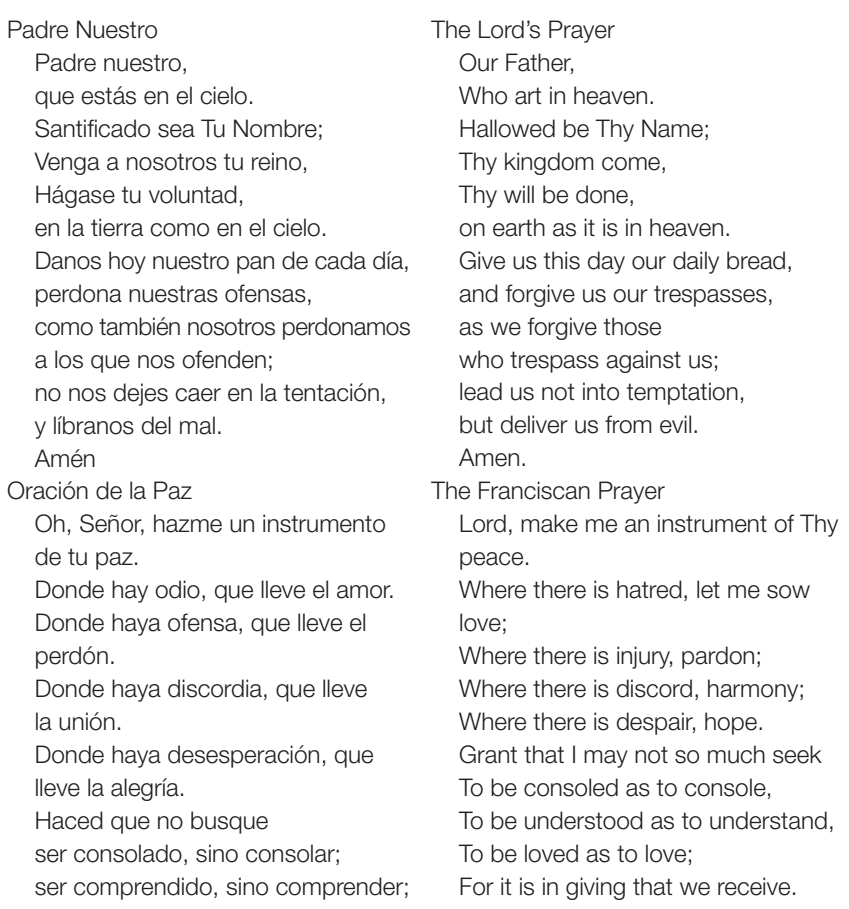

ser amado, sino amar;

Porque es dando, que se recibe.

Las Mañanitas

Estas son las mañanitas

que cantaba el rey David.

Hoy por ser día de tu santo

te las cantamos aquí.

Despierta mi bien despierta.

Mira que ya amaneció.

Ya los pajaritos cantan,

la luna ya se metió.

¡Qué linda está la mañana

en que vengo a saludartej

¡Venimos todos con gusto

y placer a felicitarte;

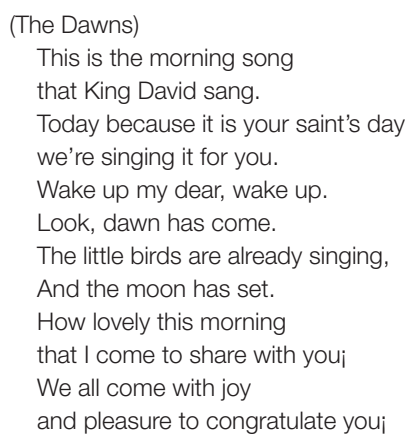

For the Franciscan tradition, human beings can only be understood as relational properties where the self and others are two interdependent spiritual and corporal entities. Contemplation and meditation are considered dual fundamental practices required to empty one's concerns and anxieties in order to develop compassion and be more receptive to others' concerns and needs (Brice and Kourie, 2006). Contemplation and compassion are primarily considered as visual imagined experiences, which then translate into actions evoking insights about one's own and others' human conditions. Since Franciscan labor focuses on alleviating human suffering, their Ministry aims to alleviate others' pain, take into account their emotions, offer solidarity, and avoid criticism as a first step toward healing and reconciliation or acceptance of the individual's condition. In this sense, the Franciscan spiritual domain embraces social affective elements (Blastic, 1997).

The Franciscan Prayer was incorporated as a fundamental text in the "Twelve Steps and Twelve Traditions" program carried out by Alcoholic Anonymous (AA), a support group 
formed in 1935 to face alcoholism. Several social initiatives and healthcare institutions now use their proposals and strategies to treat addictions (Dermatis and Galanter, 2016). Although AA does not represent an organized religion, it attempts to elaborate spiritual reflections as each of its members understand them, and underlines cooperation and empathy as crucial skills for their work (Alcohólicos Anónimos, 1986). As in the Franciscan Prayer, AA members pray to develop their own abilities and attitudes to serve and cooperate with others based on the notion that their own safety depends on the safety of others. The prayer guides the individual in a meditation on his or her own defects with humility, without pride, and avoids moral judgments of themselves and others. Similar to the Franciscan tradition, prayer and meditation are considered as imagined experiences to prepare actions to forgive, live with happiness, and help anyone in need (Alcohólicos Anónimos, 2016).

This study aimed to identify the neurocognitive function and emotional experiences in a group of Mexicans who defined themselves as atheists when reading and thinking about the Franciscan Prayer and evaluate how it elicits empathic, compassionate, and cooperative attitudes. To attain this objective, three different kinds of sequential assessments were performed. First, psychometric instruments were applied to evaluate levels of perceived well-being, acceptance of religion, and dispositional empathy. Second, brain functional images were acquired to identify BOLD signals that correlated to reading The Franciscan Prayer. Since these functional images are analyzed through statistical contrasts of the metabolic signals presented in different cognitive conditions (Raichle, 2001), The Lord's Prayer was used as a contrasting condition representing a typical Catholic text with no Franciscan elements. Further, since the Lord's Prayer is a well-known text in Mexican culture, another contrasting condition was inserted using Las Mañanitas (Mexican serenade sang at birthday parties, literally translated as Little Morning or Little Dawns) to represent a traditional non-religious text that is used in Mexican society at birthday celebrations.

The final assessment represented a qualitative enquiry based on phenomenology, which suggests that individuals can consciously transmit their experience in first person when performing a cognitive task and responding interviews (Varela and Shear, 1999). Their testimonies add both an individual and a collective perspective to understand specific situations (D'Andrade, 2001). So, interviews based on a previously elaborated script were performed to search for emotional experiences and social situations associated with reading each text.

Taking into account the suggested properties of The Franciscan Prayer, we expected activation of the sensorial, motor, and visual brain regions related to imagined actions, as well as, the ACC, which is related to complex cooperative decision-making. Given the participants' atheism, we expected activation in the orbitofrontal cortex (OFC) and the ACC when reading the Lord's Prayer, since they are related to social cognition for emotionally based conflictive decisions. Regarding the participants' experiences, we expected their testimonies to be congruent with the cognitive functions associated with the brain regions identified while they read each text.

\section{MATERIALS AND METHODS}

\section{Participants}

Twenty undergraduate students at the Universidad Autónoma de Querétaro, Mexico, and self-declared atheists (10 women, $M$ age $=22.85 \pm 2.60$ years, min. 19 , max. 27) were recruited. Participants were right-handed as measured by The Edinburgh Handedness Inventory, and had good mental health as verified by a neuropsychiatric interview. Written informed consent was obtained from the participants after the nature of the experiment was explained. The protocol was approved by the Institutional Review Board, Institute of Neurobiology, Universidad Nacional Autónoma de México, and was made according to the Ethical Principles that were proposed by the American Psychological Association (2002), the Declaration of Helsinki, and the Ethical Code for Psychologists in Mexico (Sociedad Mexicana de Psicología, 2009).

\section{Psychometric Evaluation}

Before the fMRI scanning each participant took three psychometric tests in a room with equal light conditions, timing, and directions for all participants.

The Spiritual Well-Being Scale is a Mexican version (MonteroLópez and Sierra, 1996) of the scale elaborated by Paloutzian and Ellison (1982). This scale evaluates perceived well-being in the context of spiritual quality of life according to the individual's own values and affective needs. It uses 19 items to qualify two factors: (a) the Relation with God factor evaluates a divine spirituality where individuals measure their well-being based on a self-evaluation about their relationship with God; (b) the Existential Satisfaction factor evaluates an existential spirituality where individuals measure their well-being based on their self-evaluated satisfaction regarding their own sense of life. Each item is rated in a Likert scale from 1 to 6 to identify whether individuals agree on the statement describing their satisfaction: $1=$ completely agree, $2=$ agree, $3=$ moderately agree, $4=$ moderately disagree, $5=$ disagree, $6=$ completely disagree; the higher the score the more well-being is associated with the factor.

The Religious Socialization Scale (Fernández-Díaz, 1993) is an instrument that was elaborated for young Mexican people to evaluate religious socialization. In the context of this test, religious socialization is understood as a psychosocial phenomenon through which religion integrates individuals into social groups based on their relationship with God. It includes 22 items that evaluate three factors: (a) the Church and Liturgy factor evaluates the individual's perception of liturgical rites and acts and whether they strengthen their faith; (b) the Hierarchy and Suffering factor evaluates the individual's obedience of the Church's orders or mandates; (c) the Social Justice factor evaluates the individual's perception of the church's involvement in solving social problems. Each item is rated according to a Likert scale from 1 to 4 to identify how strongly the individual agrees with the statement regarding their acceptance of religious socialization: $1=$ completely disagree, 2 = disagree, $3=$ agree, $4=$ completely agree. Therefore, higher scores in each factor indicate a greater acceptance of religious socialization. 
The Interpersonal Reactivity Index is a Spanish version (Pérez-Albéniz et al., 2003) of the instrument elaborated by Davis (1980) and has been applied previously among Mexican samples (Mercadillo et al., 2014). It evaluates dispositional empathy in four dimensions: (a) Perspective Taking or the ability to adopt the other's point of view; (b) Fantasy or tendency to empathize with fictional characters; (c) Empathic Concern representing compassion for another's situation; (d) Personal Distress or discomfort when witnessing others in aversive situations. It comprises 18 items rated with a Likert scale from 0 to 4 where 0 indicates that the factor does not describe the participant's attitudes at all and 4 indicates that the factor completely describes the participant's attitudes; high scores in each dimension indicate a more empathic attitude.

A database of the scores for the psychometric instruments was elaborated in SPSS 20.0. Considering the reduced $n=20$ sample, the Shapiro-Wilk test was executed in order to verify the normal distribution of data. In the Spiritual Well-Being Scale, the Relation with God factor did not show a normal distribution ( $W=0.843, p=0.004$ ) but the Existential Satisfaction factor $\operatorname{did}(W=0.962, p=0.592)$. None of the factors included in the Religious Socialization Scale presented a normal distribution: Church and Liturgy $(W=0.897, p=0.036)$, Hierarchy and Suffering $(W=0.731, p=0.000)$, and Social Justice $(W=0.892$, $p=0.029)$. The four factors included in the Interpersonal Reactivity Index also presented a normal distribution: Perspective Taking $(W=0.977, p=0.886)$, Fantasy $(W=0.953, p=0.416)$, Empathic Concern $(W=0.968, p=0.702)$, and Personal Distress $(W=0.960 p=0.552)$.

According to the Shapiro-Wilk test's results showing that the Spiritual Well-Being Scale did not present a normal distribution, comparisons between the values given for the factors conforming the scale (Relation with God factor and Existential Satisfaction factor) were executed by applying the Mann-Whitney $U$ test, which is used as a non-parametric test to observe differences between two randomly selected values based on the median. Also based on the Shapiro-Wilk test's results showing that the Religious Socialization Scale did not present a normal distribution, comparisons between the values given for the factors conforming the scale (Church and Liturgy factor, Hierarchy and Suffering factor, and Social Justice factor) were executed by applying the Kruskal-Wallis test, which is a non-parametric test used to observe differences of median ranks given for three or more selected values. Since the Shapiro-Wilk test's results showed a normal distribution for the values given for the four factors conforming the Interpersonal Reactivity Index, an ANOVA test was executed followed by the Tukey HSD as a post hoc test to observe specific differences between the factors. Since not all factors of the three psychometric applied instruments presented a normal distribution, the non-parametric Spearman correlation coefficient was executed to observe relations between the values comprising the three instruments.

\section{Brain Functional Scanning and Analysis}

The functional MRI session consisted of a block designed task implemented in the E-prime software version 2.0 (e-Prime Psychology software tools, Inc., Pittsburgh, PA, USA) alternating three reading conditions: the Franciscan Prayer represented the Catholic religious text of interest based on the Franciscan tradition; the Lord's Prayer represented a condition to control the effect of reading a traditional Catholic religious text that did not represent the Franciscan tradition; and since The Lord's Prayer is a traditional cultural text in Mexico, Las Mañanitas (the Mexican happy birthday folk song) was used to control the effect of reading a traditional non-religious text in Mexican society. As part of the recruitment and before the experiment, volunteers were asked about their knowledge of the three texts. In all cases, participants indicated that they were familiar with The Lord's Prayer and Las Mañanitas, but did not know The Franciscan Prayer. Table 1 presents the texts used in Spanish and their equivalent translation into English.

The task was implemented using the E-Prime software. A pilot study was performed to verify that people could read each text in $30 \mathrm{~s}$. Some minor modifications were made, which did not alter the meaning and main statements of the original texts in Spanish in order to adjust the length of the texts to a maximum of 60 words.

Once in the scanner, participants saw the texts in black letters on a white screen $(110 \mathrm{~cm} \times 70 \mathrm{~cm})$, placed $2 \mathrm{~m}$ away from their face and through a head coil mirror. Participants were instructed to carefully read each text. To verify the proper performance of the task, participants were instructed to press a button after finishing reading each text using a ResponseGrip (Nordic Neurolab Bergen, Norway). To neutralize the effect of lateralized finger motor responses, half of the participants used their right index finger while the rest used the left one.

The experiment consisted in three separate runs. Within each run subjects were consecutively presented with the three texts in a semi random order. In order to favor the return to basal functional states, a fixation cross was projected during $10 \mathrm{~s}$ before and after each text and at the end of the run. A detailed illustration and explanation of the task is shown in Figure 1.

Brain images were acquired in a 3 T DISCOVERY MR750 GE MRI scanner (General Electric Company USA), 32-channel coil, at the Resonance Magnetic Unit, Institute of Neurobiology, Universidad Nacional Autónoma de México. Anatomical high-resolution images were acquired using a 3D SPGR (spoiled gradient sequence) protocol: 272 slices, $\mathrm{TR}=8.2 \mathrm{~ms}, \mathrm{TE}=3.2 \mathrm{~ms}$, flip angle $=12^{\circ}$, matrix $=256 \mathrm{~mm} \times 256 \mathrm{~mm}$, with $1 \mathrm{~mm} \times 1 \mathrm{~mm} \times 1 \mathrm{~mm}$ resolution voxels. Functional images were acquired using a BOLD EPI-GRE (blood-oxygen level dependent echo planar imaging gradientecho) protocol: 34 slices, 4-mm thick slices with cero separation, $\mathrm{TR}=2,000 \mathrm{~ms}, \mathrm{TE}=40 \mathrm{~ms}$, flip angle $=90^{\circ}, \mathrm{FOV}=25.6 \mathrm{~cm}$, matrix $=64 \mathrm{~mm} \times 64 \mathrm{~mm}$.

The original DICOM files were converted into NIFTI format using dcm2nii (Chris Rorden's MRIcron, copyright 2012) to analyze functional images on FSL (FMRIB Software Library) (Smith et al., 2004). Voxels belonging to the neck and other non-brain tissues were eliminated for each participant's series of images by using the BET software. Functional images were analyzed using the FEAT tool (FMRI Expert Analysis Tool) implemented in FSL with statistical execution based on the General Lineal Model. Pre-statistics analysis included time slice correction to synchronize inter-slice time differences and realignment for 


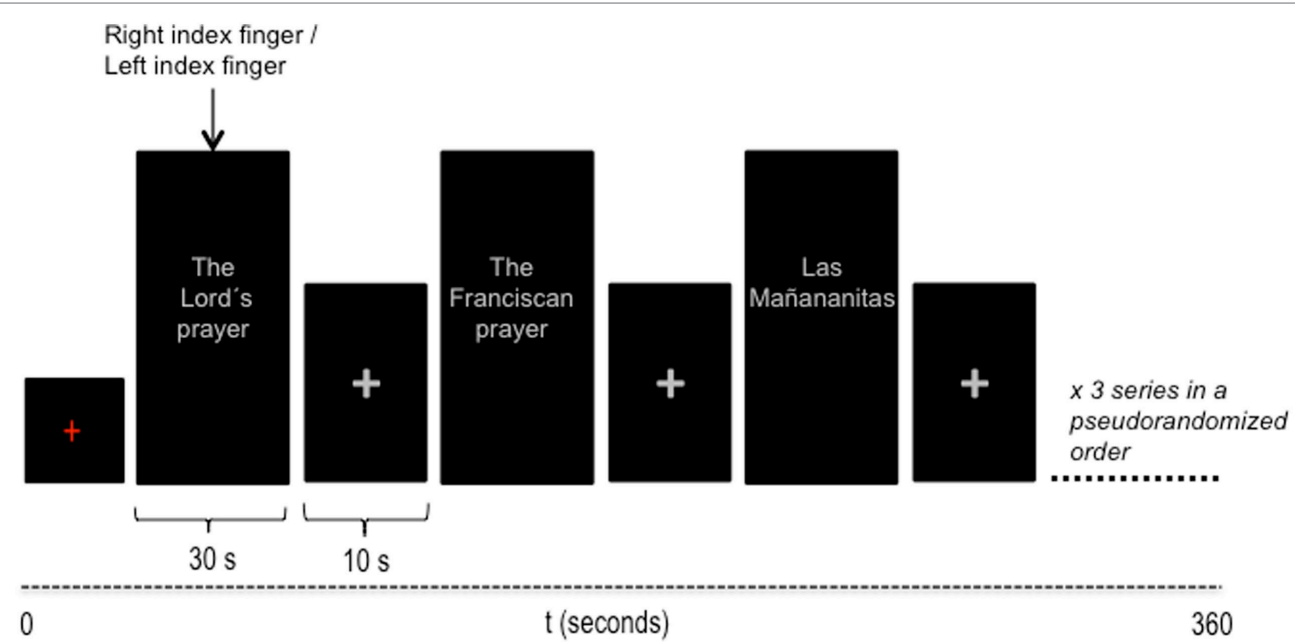

FIGURE 1 | Graphic representation of the block design applied to identify how brain function correlated with the reading of religious and non-religious texts. The task initiated with a fixation cross. Afterward, a text was projected during $30 \mathrm{~s}$. Participants were instructed to carefully read each text and to press their index finger in an IFIS response system when finishing their reading; half of the participants followed this instruction using their right index finger while the rest used the left one. After the text, a fixation cross was projected during $10 \mathrm{~s}$. Three conditions were alternated representing a series: a traditional religious text (The Lord's Prayer), the religious text of interest (The Franciscan Prayer), and a traditional non-religious text (Las Mañanitas). Each series was presented three times with an equivalent pseudorandomized order for all the participants.

head movement; the resulting images were softened by applying an isotropic Gaussian $3 \mathrm{~mm}$ kernel. Also, all brain volume images for each participant were co-registered with their high-resolution images previously processed by BET, and were normalized into the MNI 152 standard brain anatomical template proposed by the Montreal Neurological Institute.

Statistical analysis was performed at a first level for each participant's volumes and an Explicative Variables design (EV) was elaborated to identify the three conditions represented in the cognitive task: EV1 = The Lord's Prayer, EV2 = The Franciscan Prayer; EV3 = Las Mañanitas. Then, a matrix for statistical contrast between variables was performed: EV1 $>$ EV2 $=$ The Lord's Prayer vs. The Franciscan Prayer; EV1 > EV3 = The Lord's Prayer vs. Las Mañanitas; EV2 $>$ EV1 = The Franciscan Prayer vs. The Lord's Prayer; EV2 $>$ EV3 = The Franciscan Prayer vs. Las Mañanitas; EV3 > EV1 = Las Mañanitas vs. The Lord's Prayer; EV3 > EV2 = Las Mañanitas vs. The Franciscan Prayer. For this analysis, the resulting brain images were adjusted to the General Linear Model (GLM), which allows statistical testing to compare or identify differences between the values given for more than three different conditions (in this case, the BOLD values obtained for images resulted for the three compared conditions: EV1, EV2, and EV3). The statistical parametric maps of brain activity considered a threshold based on the Random Field Theory (or clusters' correction) to minimize statistical Type I error caused by multiple comparisons (Worsley, 2001). The statistical results are presented in $Z$ values and $p$-values to be interpreted; only clusters (or voxels grouped in a determined brain image region) identified as active with a $Z \geq 2.3$ threshold and $p \leq 0.05$ were accepted for the showed results.

A second level of statistical analysis was made of all the participants' brain volumes using the FLAME tool (FMRIB's Local Analysis of Mixed Effects) implemented on FSL and well used to analyze fMRI studies (Smith et al., 2004). Cluster centroid coordinates of brain activation were estimated using the MNI 152 brain template. The Talairach Daemon Client system (Lancaster et al., 2000) and the fslview software were used to obtain the approximate Brodmann's area. The GLM and the rigorous statistical corrections applied by the FSL system in an fMRI study constitute a feasible method to analyze and interpret the brain function related to a cognitive task considering a sample of 20 participants (Poldrack, 2012; Chen and Glover, 2015).

\section{Qualitative Enquiry}

Some qualitative approaches suggest that individuals can consciously transmit their experience in a first person style when performing a cognitive task by applying designed interviews. The interviewer must be a respectful person who can access the interviewed person's points of view. Reports obtained from a first person perspective are considered as qualitative data and translated into third-person narrative to acquire a sense of objectivity and be interpreted. These data are grouped in clusters or categories that then represent the global experience of an individual or a group (Varela and Shear, 1999; Olivares et al., 2015). Following to this approach and after the resonance imaging scanning, interviews were conducted for each participant about their emotional experience while reading each of the three texts.

The interviews were audio-recorded and based on a previously designed script to search for four aspects: (1) What the participants felt during their reading; (2) How they define their experience and/or feelings; (3) Why they think they felt or experienced them; and (4) What differences they identified when reading the three texts and why these differences were presented. For all cases, the participants' testimonies were confidential and they were informed that the material would only be used as part 
of this research. After being transcribed, interviews were then listened, read, and analyzed separately by two experts in qualitative analysis. Through these analyses, they were able to identify the main variables that represent the different experiences that came up when answering the four questions. Variables obtained in the analyses were divided and named as experiential categories.

\section{RESULTS}

\section{Psychometric Assessment}

For The Spiritual Well-Being Scale, the Existential Satisfaction factor presented higher scores than the Relation with God factor $(z=-3.84, p=0.00)$. The three factors included in The Religious Socialization Scale presented significant differences $\left[X_{(2)}^{2}=12.43, p=0.002\right]$ but all represented a disagreement with religious socialization. Differences were found for factors included in the Interpersonal Reactivity Index $\left[F_{(2,79)}=13.65\right.$, $p=0.00]$, where Personal Distress manifested lower scores. Descriptive statistics and significant differences are presented in Table 2.

Ratings for the Relation with the God factor under The Spiritual Well-Being Scale positively correlated with the Church and Liturgy factor of The Religious Socialization Scale $\left(r_{s}=0.735, p=0.00\right)$, while ratings for the Existential Satisfaction factor negatively correlated with the Social Justice factor

TABLE 2 | Descriptive statistics (means, SD, and median) for the factors included in each psychometric instrument.

\begin{tabular}{lllll}
\hline $\begin{array}{l}\text { Psychometric } \\
\text { instrument }\end{array}$ & Instrument's factor & Mean & SD & Median \\
\hline Spiritual well-being & Relation with God & 2.42 & 1.44 & 1.49 \\
scale* $^{*}$ & Existential satisfaction & 4.41 & 0.89 & 4.43 \\
Religious socialization $_{\text {scale* }}$ & Church and liturgy $^{\mathrm{a}}$ & 1.81 & 0.69 & 1.66 \\
& Hierarchy and suffering $^{\mathrm{b}}$ & 1.45 & 0.65 & 1.16 \\
Interpersonal reactivity $_{\text {index }}^{*}$ & Social justice $^{\mathrm{c}}$ & 2.16 & 0.62 & 2.25 \\
& Perspective taking $^{\mathrm{a}}$ & 2.66 & 0.61 & 2.71 \\
& Fantasy $^{\mathrm{a}}$ & 2.44 & 0.74 & 2.49 \\
& Empathic concern $^{\mathrm{a}}$ & 2.57 & 0.48 & 2.62 \\
& Personal distress $^{\mathrm{b}}$ & 1.55 & 0.59 & 1.58 \\
\hline
\end{tabular}

The Spiritual well-being scale is rated from 1 to 6 , where 1 represents that the participant completely agrees with the attitude's description and 6 represents that the participant completely disagrees; a higher score indicates more spiritual well-being is associated with the factor. *Indicates significant differences between the values given for the two factors conforming the scale at $p \leq 0.05$ according to the results obtained from Mann-Whitney $U$ test. The Religious socialization scale is rated using a scale from 1 to 4 , where 1 represents that the participant completely disagrees with the attitude's description and 4 represents that the participant completely agrees; a higher score indicates more religious socialization. *Indicates significant differences between the values given for the three factors conforming the scale at $p \leq 0.05$ according to the results obtained from the Kruskal-Wallis test; different superscripts indicate specific differences between the factors and represent that the scores given for three factor are statistically different between them. The Interpersonal reactivity index is rated using a scale from 0 to 4 where 0 represents that the factor does not describe the participant's attitude at all and 4 represents that the factor completely describes the participant's attitudes; higher scores indicate more empathic attitudes. *Indicates significant differences between factors at $p \leq 0.05$ according to the results obtained from ANOVA test; different superscripts indicate specific differences between the factors according to the post hoc Tukey HSD test and represent that only the scores given for the Personal Distress factor is statistically different than the other three factors. $\left(r_{\mathrm{s}}=-0.680, p=0.01\right)$. No other correlation was found between the Interpersonal Reactivity Index and other instruments.

\section{Brain Function}

Clusters with significantly larger BOLD signal activations while reading The Franciscan Prayer in contrast to The Lord's Prayer were located in primary motor and premotor cortices, as well as in the occipital primary and associative cortices. The contrast between The Franciscan Prayer and Las Mañanitas revealed larger occipital and premotor activation, as well as larger parietal activation in primary and integrative areas (see Table 3 and Figure 2).

When The Lord's Prayer was contrasted with The Franciscan Prayer, BOLD signals were located in bilateral prefrontal and orbitofrontal cortices, and in the right inferior frontal and right supplementary motor cortices. Bilateral activation was also present in parietal and limbic regions covering the anterior and posterior cingulate cortices. For the contrast between the Lord's Prayer and Las Mañanitas, larger activation was presented in the right associative somatosensory, premotor and posterior cingulate cortices, in the parieto-occipital junction comprising the cuneus, and in the cerebellar declive (see Table 3 and Figure 2).

Clusters with larger activation for Las Mañanitas than with The Franciscan Prayer were identified in the right temporal pole, and the inferior frontal and orbitofrontal cortices. The contrast between Las Mañanitas and The Lord's Prayer did not reveal any significant difference in activation, suggesting similar processes (see Table 3 and Figure 2).

\section{Qualitative Inquiry}

Results are presented in a typical third-person phenomenological narrative and some translated quotes of the participants' declarations are shown to illustrate our interpretations. Table 4 summarizes the experiential categories identified for the group of 20 participants.

Regarding their feelings during the reading of The Franciscan Prayer, most of the participants' testimonies were related to experiences of "liking" which were categorized according to phrases such as "I like...," or phrases indicating experiences of "happiness," "wellness," "love," and "safety." These experiences were connected with cooperative attitudes, reciprocity, and collectivism interpreted in the prayer. For example:

... even if I'm not a religious person...some words are very harmonic.... such as, love, forgiveness, union, things like that... happiness, comfort. It makes me.... feel good.... like it repeated those words, keeping them in mind (woman, 24 years old).

Additionally, these experiences were linked to personal participants' memories and beliefs about the world:

... it is a good message and would help everyone: 'Where there is pain, love should be given'. Because it would work for me right now, because of everything I've been going through ... 'It is in giving that we receive', it is mutual (man, 19 years old). 
TABLE 3 | Activated brain regions for all participants identified by BOLD signal correlated with the reading of religious and non-religious texts: religious text of interest contrasted with a traditional religious text (The Franciscan Prayer > The Lord's Prayer), religious text of interest contrasted with a traditional non-religious text (The Franciscan Prayer > Las Mañanitas), traditional religious text contrasted with the religious text of interest (The Lord's Prayer > The Peace Prayer), traditional religious text contrasted with a traditional non-religious text (The Lord's Prayer > Las Mañanitas), traditional non-religious text contrasted with the religious text of interest (Las Mañanitas > The Franciscan Prayer), and traditional non-religious text contrasted with a traditional religious text (Las Mañanitas > The Lord's Prayer).

\begin{tabular}{|c|c|c|c|c|c|c|c|}
\hline \multirow[b]{2}{*}{ Anatomical region } & \multirow[b]{2}{*}{ L/R } & \multirow[b]{2}{*}{ BA } & \multirow[b]{2}{*}{ Cluster size } & \multirow[b]{2}{*}{$Z$ value } & \multicolumn{3}{|c|}{ MNI coordinates } \\
\hline & & & & & $x$ & $y$ & $z$ \\
\hline \multicolumn{8}{|c|}{ The Franciscan Prayer > The Lord's Prayer } \\
\hline Precentral gyrus & $L$ & 4 & 1,141 & 4.83 & -54 & -8 & 40 \\
\hline Precentral gyrus & $\mathrm{L}$ & 6 & & 4.11 & -46 & -6 & 48 \\
\hline Inferior occipital gyrus & $\mathrm{L}$ & 18 & 889 & 4.06 & -24 & -86 & -10 \\
\hline Fusiform gyrus & $\mathrm{L}$ & 18 & & 3.64 & -24 & -94 & -12 \\
\hline Lingual gyrus & $\mathrm{L}$ & 17 & & 3.16 & -14 & -84 & -2 \\
\hline Cuneus & $\mathrm{L}$ & 17 & & 3.09 & -12 & -78 & 8 \\
\hline \multicolumn{8}{|c|}{ The Franciscan Prayer > Las Mañanitas } \\
\hline Superior parietal lobule & $\mathrm{R}$ & 7 & 9,303 & 4.85 & 30 & -60 & 48 \\
\hline Middle occipital gyrus & $R$ & 18 & & 4.46 & 32 & -88 & -2 \\
\hline Fusiform gyrus & $\mathrm{R}$ & 37 & & 4.33 & 46 & -54 & -12 \\
\hline Precentral gyrus & $L$ & 6 & 1,523 & 3.97 & -60 & -6 & 34 \\
\hline Postcentral gyrus & $\mathrm{L}$ & 3 & & 3.58 & -60 & -16 & 28 \\
\hline \multicolumn{8}{|c|}{ The Lord's Prayer > The Franciscan Prayer } \\
\hline Inferior frontal gyrus & $\mathrm{R}$ & 11 & 3,264 & 4.57 & 26 & 44 & -16 \\
\hline Middle frontal gyrus & $\mathrm{R}$ & 10 & & 4.16 & 38 & 62 & -6 \\
\hline Inferior frontal gyrus & $\mathrm{R}$ & 47 & & 3.9 & 40 & 28 & -16 \\
\hline Inferior frontal gyrus & $\mathrm{R}$ & 45 & & 3.89 & 56 & 18 & 10 \\
\hline Superior frontal gyrus & $\mathrm{R}$ & 8 & 2,781 & 4.06 & 18 & 30 & 50 \\
\hline Angular gyrus & $\mathrm{R}$ & 39 & 2,689 & 4.65 & 50 & -64 & 30 \\
\hline Inferior parietal lobule & $\mathrm{R}$ & 40 & & 3.93 & 62 & -26 & 34 \\
\hline Middle frontal gyrus & $\mathrm{L}$ & 47 & 2,131 & 5.2 & -30 & 36 & -10 \\
\hline Middle frontal gyrus & $\mathrm{L}$ & 11 & & 4.58 & -36 & 36 & -14 \\
\hline Cíngulate gyrus & $L$ & 31 & 1,432 & 4.07 & 0 & -40 & 36 \\
\hline Cíngulate gyrus & $\mathrm{R}$ & 24 & & 3.53 & 4 & -18 & 36 \\
\hline Inferior parietal lobule & $\mathrm{L}$ & 40 & 1,132 & 4.11 & -52 & -60 & 42 \\
\hline \multicolumn{8}{|c|}{ The Lord's Prayer > Las Mañanitas } \\
\hline Paracentral lobule & $\mathrm{R}$ & 5 & 5,549 & 4.52 & 2 & -32 & 48 \\
\hline Posterior cingulate & $\mathrm{R}$ & 31 & & 4.36 & 2 & -18 & 46 \\
\hline Middle frontal gyrus & $\mathrm{R}$ & 6 & & 4.03 & 4 & -22 & 50 \\
\hline Transverse temporal gyrus & $\mathrm{R}$ & 42 & & 3.86 & 62 & -10 & 12 \\
\hline Posterior cingulate & $L$ & 31 & & 3.83 & -8 & -30 & 48 \\
\hline Cuneus & $\mathrm{L}$ & 17 & 3,852 & 4.67 & -10 & -96 & 4 \\
\hline Cerebellum (Declive) & $\mathrm{R}$ & * & & 4.1 & 26 & -80 & -22 \\
\hline \multicolumn{8}{|c|}{ Las Mañanitas > The Franciscan Prayer } \\
\hline Superior temporal gyrus & $\mathrm{R}$ & 38 & 743 & 3.61 & 56 & 22 & -14 \\
\hline Inferior frontal gyrus & $\mathrm{R}$ & 45 & & 3.25 & 54 & 24 & 0 \\
\hline Inferior frontal gyrus & $\mathrm{R}$ & 47 & & 3.22 & 50 & 28 & -2 \\
\hline \multicolumn{8}{|c|}{ Las Mañanitas > The Lord's Prayer } \\
\hline
\end{tabular}

*Indicates that no BA is located.

Results at $p<0.05$.

L, left; R, right; BA, approximate Brodmann's area located by using the Talairach Deamon Client system; MNI coordinates, coordinates indicating the brain region location according to the Montreal Neurological Institute 152 standard brain template; cluster size, number of voxels comprising the extended located brain region.

Null means that no activated brain region was identified for the contrast, implying that a similar brain function is presented in both conditions.

...I think it is very.... utopian ....it has a.... certain feeling... between humility and idealism ... the way it should be... in order to have a.... better world... the common good for everyone (man, 19 years old).

Liking The Franciscan Prayer was related to a notion of responsibility for personal actions too. For example:

You become a tool, you are also a creator of the circumstances and consequences... the other person needs me to be strong in order [for them] to be strong (woman, 25 years old).

Some empathic elements involved in how interpersonal relations motivate helping others were also mentioned as reasons for the experience of liking. For example:

Put yourself in the other person's shoes; and especially the part that I loved was what it said about 'not be understood, but understand'... what I care about is 
1. The Lord's prayer > The Franciscan prayer

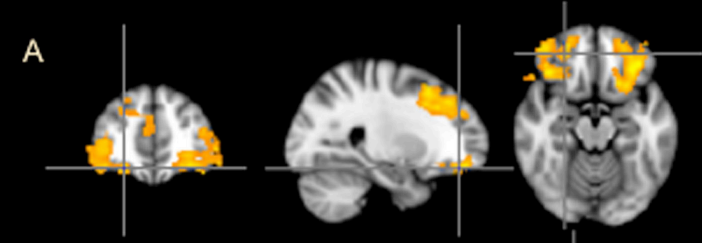

B

3
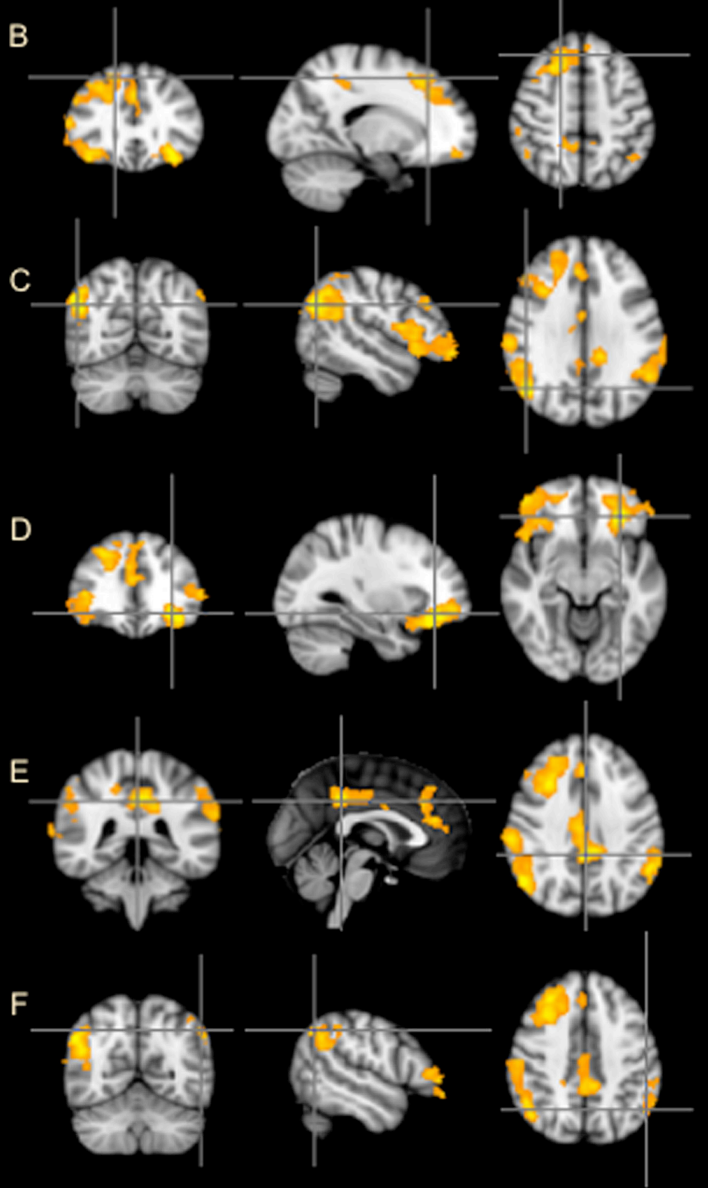

2. The Lord's prayer > Las Mañanitas

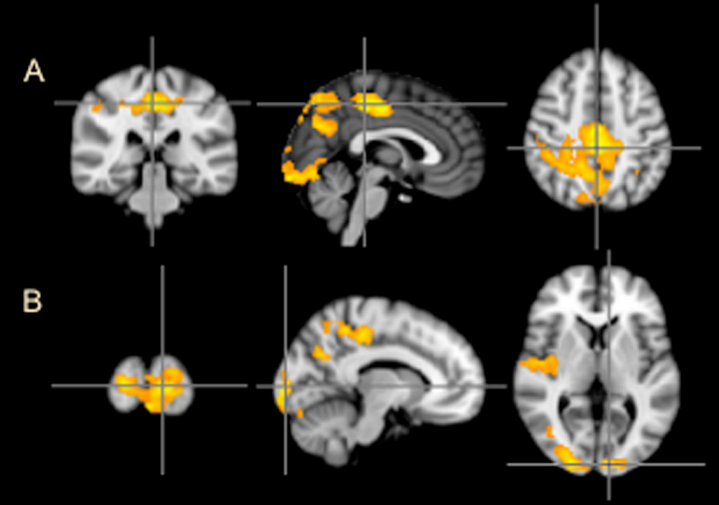

3. The Franciscan prayer > The Lord's prayer

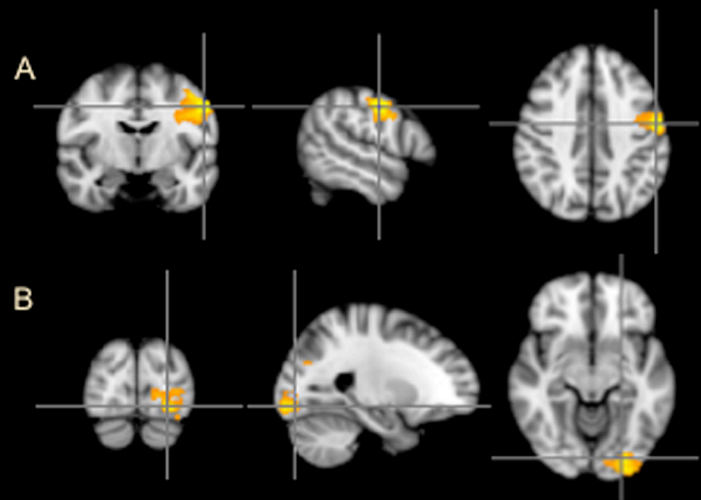

4. The Franciscan prayer > Las Mañanitas

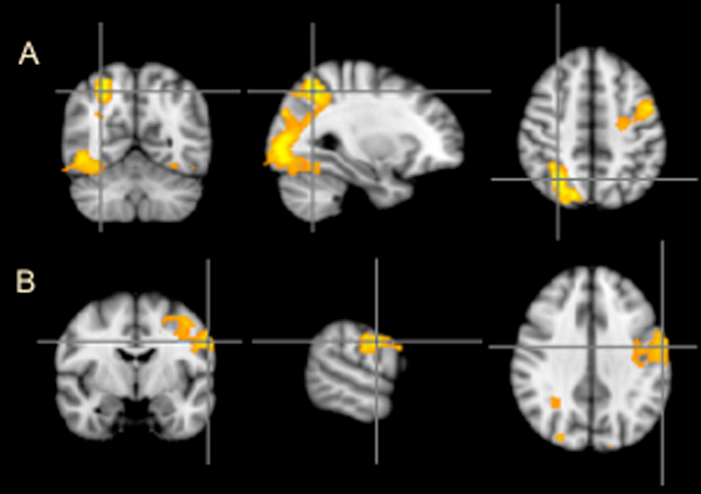

5. Las Mañanitas > The Franciscan prayer

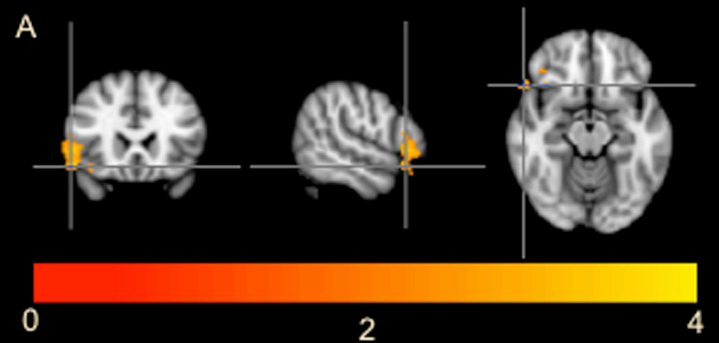

6. Anatomical reference

Coronal Sagittal Axial

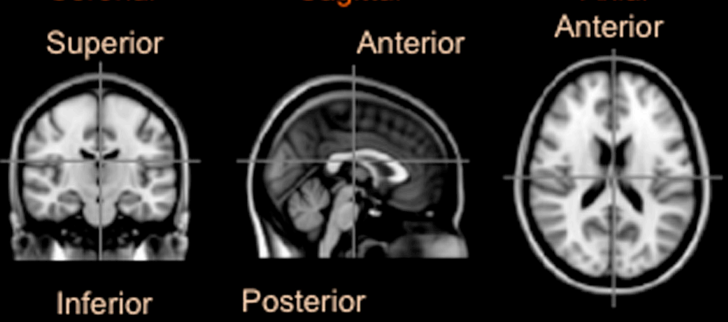

Posterior

Right Left 
FIGURE 2 | Coronal, sagittal, and axial views illustrating the main clusters for the activated brain regions identified by BOLD signal correlated with the reading of religious and non-religious texts. (1) The Lord's Prayer > The Franciscan Prayer, representing a traditional religious text contrasted with the religious text of interest: (A) inferior and middle frontal cortices, (B) superior frontal cortex, [(1), C] parietal cortex including angular gyrus, [(1), D] middle frontal cortex, (E) cingulate gyrus, and (F) inferior parietal cortex. (2) The Lord's Prayer > Las Mañanitas, representing a traditional religious text contrasted with a traditional non-religious text: [(2), A] paracentral and posterior cingulate cortices. [(2), B] cuneus and cerebellum. (3) The Franciscan Prayer > The Lord's Prayer, representing the religious text of interest contrasted with a traditional religious text: [(3), A] precentral cortex, [(3), B] occipital cortex including fusiform and lingual gyri. (4) The Franciscan Prayer > Las Mañanitas, representing the religious text of interest contrasted with a traditional non-religious text: [(4), A] parietal and occipital cortices including fusiform gyrus, [(4), B] precentral and postcentral cortices. (5) Las Mañanitas > The Franciscan Prayer, representing a traditional non-religious text contrasted with the religious text of interest: [(5), A] temporal and frontal cortices. (6) Anatomical references to locate the illustrated brain regions. Red-yellow bar represents the $Z$ values threshold.

TABLE 4 | Summary of the main feelings reported by participants during the interview on their experience while reading The Franciscan Prayer, The Lord's Prayer, and Las Mañanitas.

\begin{tabular}{|c|c|c|c|}
\hline Text & Experiential category & $\begin{array}{l}\text { Indicatory terms for } \\
\text { categories }\end{array}$ & Associated contexts, actions, and assumptions \\
\hline \multirow[t]{10}{*}{ The Franciscan Prayer } & Liking (14) & Liking & Motivation for cooperative actions. \\
\hline & & Wellness & Motivation to forgive, to understand, and to comfort somebody else. \\
\hline & & Love & Empathic attitudes. \\
\hline & & Happiness & Reciprocity. \\
\hline & & Safety & Responsibility for own decisions and actions. \\
\hline & & & Notion of oneness. \\
\hline & Apathy (5) & Nothing & Lack of a religious identity. \\
\hline & Rejection & Disgust & Lack of a religious identity. \\
\hline & Disgust (3) & Discomfort & $\begin{array}{l}\text { Expressions of pity and humiliation. } \\
\text { Involvement of God. }\end{array}$ \\
\hline & $\begin{array}{l}\text { Submissiveness } \\
\text { Fear (1) }\end{array}$ & $\begin{array}{l}\text { Submissiveness } \\
\text { Fear }\end{array}$ & Thinking something or somebody else controls someone's actions. \\
\hline \multirow[t]{17}{*}{ The Lord's Prayer } & Apathy (10) & Nothing & Lack of a religious identity. \\
\hline & & Apathy & Meaningless. \\
\hline & & Boredom & Family and school memories during the participants' childhood. \\
\hline & Liking (9) & Liking & A useful moral system for a better way of life. \\
\hline & & Happiness & Attitudes related to forgiveness and appeal. \\
\hline & & Peace & Family and school memories during the participants' childhood. \\
\hline & & Harmony & \\
\hline & & Relaxation & \\
\hline & & Confidence & \\
\hline & Rejection & Disgust & Assumptions considered as absurd. \\
\hline & Disgust (5) & & Fanaticism. \\
\hline & & & Personal anti-religious points of view. \\
\hline & & & Family and school memories during the participants' childhood. \\
\hline & Vulnerability & Vulnerability & Thinking something or somebody else controls someone's actions. \\
\hline & Submissiveness & Submissiveness & Lack of self-responsibility. \\
\hline & Fear (4) & Fear & \\
\hline & Confusion (1) & Confusion & $\begin{array}{l}\text { Motivation for compassion and forgiveness, but restlessness and religious } \\
\text { conflicts too. }\end{array}$ \\
\hline \multirow[t]{5}{*}{ Las Mañanitas } & Liking (17) & Liking & Birthday celebration. \\
\hline & & Relief & Family and school memories during the participants' childhood. \\
\hline & & Happiness & Cultural Mexican identity. \\
\hline & & Relaxation & \\
\hline & Apathy (3) & Nothing & Habitual or regular actions and contexts. \\
\hline
\end{tabular}

Feelings were categorized according to different kinds of experiences based on the emotional terms participants manifested. Contexts, actions, and assumptions associated with each category are also presented. The number inside each experiential category represents the amount of testimonials mentioned for all the participants related with that category.

seeing the pain you're in at this moment (woman, 25 years old).

You change everyday logic...because it is in giving that you receive...I am not a victim of circumstance. I am part of the solution, not part of the problem...
I don't have the right to impose, I am here to do it sincerely... a position that is like that... (man, 19 years old).

Oriented towards others... breaks with my idea of justice... Stop thinking only about myself...it pushes you into action to help ... (man, 26 years old). 
Some experiences of liking were ambivalent since the participants considered that The Franciscan Prayer does not consider the reader's circumstances. For example:

... But I would like it more if it rescued some type of reciprocity... it doesn't consider or it doesn't mention this part of others also respecting you (woman, 21 years old).

Giving and receiving isn't always positive, it may be negative, strained (man, 23 years old).

Some statements indicated apathy ("nothing") or "disgust." Occasionally, both kinds of testimonies were connected with rejection toward the religious quality of the text and with their own lack of a Catholic identity. For example:

I didn't like it. It made me feel uncomfortable. I didn't understand it, I don't feel identified... maybe if I had been younger then I would have felt more empathy. Or if I had learned it as a kid, but... I like to think that one doesn't really reflect on these things, you just recite them (man, 24 years old).

Some experiences of apathy were connected with liking elements too. For example:

It's nice, but I didn't feel anything. It's like a best wishes card. (woman, 21 years old).

One participant indicated he experienced "fear," since The Franciscan Prayer implies a "submissive" attitude:

...I'm nobody's tool... each one of us is responsible for it. If you want to practice love rather than hate, well then practice it (man, 26 years old).

Concerning the reading of The Lord's Prayer, most of the testimonies manifested apathy, boredom, and even mockery, commonly linked to rejection toward the religious quality of the text. For example:

... I don't really care... I think it's a bit absurd...

Complete indifference (woman, 21 years old).

It gave me a strong impulse to laugh, religion is always completely absurd...fanatic (woman, 22 years old).

It's something I'm against... thy will be done and fuck whoever likes or dislikes it (man, 27 years old).

Some experiences of apathy were ambiguous since they were related to liking the social function perceived in the text. For example:

I like this prayer, but I don't feel anything, I wasn't brought up under a Catholic family tradition.... I am an atheist... I don't believe in God...however, I do believe that this moral system helps you have a better life (man, 19 years old).
Some statements indicated experiences of liking that were inferred from the mention of positive emotional terms, such as happiness, harmony, relaxation, or trust, not related to the religious quality of the text. For example:

... I do feel many things... harmony, peace, justice, salvation... forgiveness, plea, compassion... not with the religious practice, but in a type of practice with oneself... (man, 23 years old).

I liked it... putting the whole religious element aside... happiness... calm, peace. Relaxed. (man, 19 years old).

Some testimonies showed emotional terms, such as "disgust," "rejection," "vulnerability," or "submissiveness," which were categorized as experiences of disgust. For example:

There is a certain feeling of vulnerability... Because you are telling the Lord ... since I can't deal with it, give me what I need (woman, 25 years old).

... submissive to someone or something (man, 26 years old).

Most liking and disgust experiences were associated with childhood memories involving family and/or school, which may point to the historic and cultural context of The Lord's Prayer in Mexico. For example:

... It reminded me of when I was a kid... I remembered those nights when I prayed and how I used to say it... it didn't make me feel calmer, it had lost its charm (man, 24 years old).

...I memorized it when I was a little girl... It doesn't bother me ... I do not consider myself Catholic... It reminds me of nice moments with my family (woman, 22 years old).

In comparison with The Lord's Prayer, The Franciscan Prayer was clearly perceived as connected with experiences of liking and motivated cooperative, responsible, and empathic actions. These were commonly understood out of the religious quality of the text. For example:

Well, this prayer [the Franciscan Prayer]... it seems to be much more based on humans helping humans. That relates much more to empathy and generosity. I agree more with it... the language itself isn't as religious, so I could tolerate it more (woman, 22 years old).

Despite it being Catholic and all, Saint Francis of Assisi saw it as slightly more rooted in nature, right? ... It seems much more human... Even so, I still see the issue of God (man, 27 years old).

In comparison with The Franciscan Prayer, testimonies given for The Lord's Prayer showed several overlapping pleasant and unpleasant experiences. As one participant indicated, this overlapping may represent a confusion between the message of 
forgiveness perceived in The Lord's Prayer and a disagreement with the religious quality of the text, which is perceived as also promoting submissive attitudes:

In one you are vulnerable [The Lord's Prayer] and in the other [The Franciscan Prayer] you are part of the solution (woman, 25 years old).

Regarding Las Mañanitas, most participants' testimonies showed pleasant experiences inferred from the use of terms, such as happiness or wellness, linked to memories involving family and celebration. For example:

Relief. Happiness. The song made me feel ticklish. Relaxation (man, 24 years old).

Some participants indicated indifference but did allude to the cultural context of the text:

Nothing in particular. I don't really care about my birthday. It's very common (man, 27 years old).

Unlike memories evoked by The Lord's Prayer, Las Mañanitas were related to family, school, and childhood, memories and were mostly connected with happiness and affection. While inquiring after the different experiences of reading the three texts elicited, none of the participants mentioned any comparison between Las Mañanitas and The Franciscan Prayer.

\section{DISCUSSION AND CONCLUSION}

Spiritual well-being that isn't related to God is present among people who self-identify as atheists. In this study, atheists are understood as those who consider spirituality behavioral guides that are defined in a more personal way and free of regulations associated with any particular religious institution (Koenig, 2009). This notion of spirituality was assessed with the Existential Satisfaction factor of The Spiritual Well-Being Scale and represented in the main participants' profiles.

Thus, results agree with atheist participants' position and may involve existential thoughts and feelings manifested in their attitudes and views of life (Slaby and Stephan, 2008). Also, the Social Justice factor of The Religious Socialization Scale represented the instrument's lowest disagreement range. This may be due to a notion of collectivism linked to helping behaviors and the notion of social equality described in Mexican culture (Díaz-Guerrero, 2003). Religious socialization can be considered as a process through which an individual assimilates certain behavioral communal codes comprising values, beliefs, manners, and knowledge related to his/her social group (González-Blasco, 2006).

In this sense, the correlation between the Existential Satisfaction and the Social Justice factors is understandable since, although atheist participants belong to an academic group that oftentimes criticizes hierarchical and religious systems (Echavarría et al., 2007; Rodríguez and Cruz, 2014), they have generally shared and learned certain religious cultural codes throughout their life. This last assumption is relevant since the prevalence of the Catholic Church in Mexico involves codes that give existential sense to suffering and promote some guidance for cooperation and mutual support. These elements are shared with other non-religious practices related to a notion of social justice and existential components to appreciate human beings (Slaby and Stephan, 2008; Koenig, 2009).

Concerning the Interpersonal Reactivity Index, the Perspective Taking, Empathic Concern, and Fantasy dimensions all presented similar mid ratings. Hence suggesting that there is a standard empathic profile related to the cognitive regulation of emotions needed to project one's understanding of the other (Batson, 2009). Although empathy has been related to moral qualities that favor social justice (Decety and Yoder, 2016), this relation may also involve existential satisfaction and empathic dispositions understood as psychosocial elements manifested in memories and cooperative decisions, as was revealed in participants' experiences when reading The Franciscan Prayer.

Psychometric results suggest that cognitive and emotional empathic dispositions might not be explicitly allied with religious beliefs. Rather, results agree with reports suggesting a negative association between religiosity and analytic thinking as shown in academic studies that evaluate arguments related to beliefs (Tinoco, 1998; Jack et al., 2016). Accordingly, tension between religiosity and analytic thinking is present in the participant's testimonies. Even though The Franciscan Prayer evoked cooperativeness, forgiveness, and empathy, it also elicited apathy or rejection due to the religious origin of the text. Rejection and disgust were more common when reading The Lord's Prayer, which evoked cultural memories and moral principles but was scarcely associated with empathy and cooperation.

Regarding the fMRI results, clusters identified while reading The Franciscan Prayer in contrast with The Lord's Prayer were located in primary motor cortex (BA 4), which contains a somatotopic representation of the human body and is functionally related to initiating voluntary movements. Activation also included the premotor cortex (BA 6) associated with integrative functions required for complex and coordinated movements. Since no complex movements were required during the task, these activations may imply imaginary processes involving attention to sensorial and motor experiences, as observed during incited attention and imagery on own body members (Bauer et al., 2014). BOLD signals were identified in the primary (BA 17 ) and associative (BA 18) visual cortices too; their functions may be required to perform detailed analysis of imagined scenes and were previously identified when experiencing compassion (Mercadillo et al., 2011).

Further, some cognitive functions of the fusiform gyrus are related to the valuation of human faces (Doré et al., 2015) and understanding psychological properties of people when defining their social identity (Guassi-Moreira et al., 2017). The cuneus, on the other hand, has been identified when people perform imagined movements related to empathic attitudes in social contexts (Mochizuki et al., 2014). According to our hypothesis, these motor and visual functions might be essential for the empathic and cooperative elements expressed in The 
Franciscan Prayer, such as granting comfort, understanding or love, which requires intentional movement planning (Bennett and Hacker, 2005).

These sensorial functions agree with the contemplative processes related to compassionate actions of the Franciscan tradition and to the praying and meditative exercises advised in the AA program (Blastic, 1997; Alcohólicos Anónimos, 2016). Also, these neurocognitive functions are congruent with the participants' transmitted experiences of liking, love, and wellness when reading the Franciscan Prayer, since they motivate cooperative actions, forgiveness, and understanding.

The contrast of The Franciscan Prayer vs. Las Mañanitas revealed a similar visual (BA 18) and premotor (BA 6) activation to what is mentioned above. In agreement with our hypothesis, somatosensory components were identified in parietal regions related to primary (BA 3) and integrative (BA 7) functions. Since somatosensory functions are reported when inciting attention (Schwartz et al., 2005; Bauer et al., 2014), these activations suggest a conscious attention to bodily experiences related to both motor intentions and the integration of conceptual information on one's own bodily representations (Soon et al., 2008) elicited by reading The Franciscan Prayer. Moreover, based on fMRI studies involving complex decision-making, the superior parietal cortex has been proposed as essential in envisioning and performing pro-social and cooperative decisions that affect others' well-being (Emonds et al., 2014). This probable pro-social thinking was elicited while reading The Franciscan Prayer and may be better inferred when contrasted it with Las Mañanitas than when contrasted with The Lord's Prayer since this second text evidences the social and moral cognition presented in The Franciscan Prayer too (Schjoedt et al., 2009).

When contrasting the reading of The Lord's Prayer to The Franciscan Prayer, as expected, BOLD signals were identified in BA 10,11, and 47 grouped in the OFC. Some reports reveal activation of BA 10 while analyzing ironic sentences (Shibata et al., 2010) and its cognitive function is proposed for complex mnemonic and linguistic processes involving personal relevance and negative feedback of thought, decisions, and emotional traits (Gilbert et al., 2006; Soon et al., 2008; Rameson et al., 2010). Neuroimaging studies based on psychophysiological interactions suggest the role of the medial OFC (BA 11) in motivational and self-perceptual processes to regulate bottom-up sensorial information to evaluate one's own and others' relevance (Flagan and Beer, 2013). Additionally, it has been activated when performing analogical and semantic reasoning while judgment regulation is simultaneously presented with other prefrontal regions observed in this contrast too, such as BA 45 and BA 47 (Luo et al., 2003). Executive and grammatical functions, such as learning concepts and autobiographical memory, have been associated with BA 47 (Lee et al., 2014), as well as moral emotional experiences, such as disgust and indignation (Moll et al., 2005).

The linguistic and mnemonic functions associated with OFC may be needed for antagonistic and conflictive experiences and valuations based on childhood and cultural memories evoked among nonbelievers while reading The Lord's Prayer. This was manifested in the variety of emotions transmitted including apathy, liking, disgust, or even confusion. Also, according to OFC cognitive functions, participant's transmitted experiences not only involve valuations of the self but also of others' attitudes, as represented in their testimonials when mentioning someone else's fanaticism or their own anti-religious points of view.

To complement the functions mentioned above, BOLD signal was also identified in prefrontal regions comprising BA 8 and 45. The function of Brodmann 8 is related to imagined heard speeches (Tian et al., 2016) and inhibition of somato-motor processes while performing conflictive tasks. Additionally, BA 45 is related to logical reasoning by inhibiting beliefs-bias explanations (Tsujii et al., 2010) and regulates a kind of analogic intelligence to relate concepts and information (Geake and Hansen, 2005). These processes may be more salient while reading The Lord's Prayer than The Franciscan Prayer since the first one implies more categorical religious elements that conflict with atheist perspectives.

The diversity of complex functions related to the OFC are performed by networks including the frontal, parietal, and cingulate systems, observed in the contrast between The Lord's Prayer and The Franciscan Prayer. While frontopolar functions involve relational integration of abstract information, such as the moral or hierarchical codes presented in The Lord's Prayer, parieto-frontal projections, including BA 39 and 40, involve working memory to manipulate and use information to categorize and complement this integration (Babiloni et al., 2005; Green et al., 2006). Through the meta-analysis of fMRI and tractography studies, it is suggested that BA 39 allows semantic processes for verbal and non-verbal visual stimuli (Rosselli et al., 2015), while BA 40 participates in phonological comprehension when reading words (Stoeckel et al., 2009) and sentences categorized as ironic (Shibata et al., 2010). Both linguistic processes may be required to judge The Lord's Prayer since it represents a complex text when evaluated and categorized by an atheist.

As expected, larger activation of the ACC in BA 24 was identified for The Lord's Prayer vs. The Franciscan Prayer. This brain region has been related to integrating information since it involves neural interchange between temporal, premotor, parietal, prefrontal, and limbic regions in order to make complex decisions and valuations (Koski and Paus, 2000). As observed by using Positron Emission Tomography, ACC activation becomes greater as decision-making becomes more difficult and includes social-cognitive elements where brain function also involves BA 10, 11, and 47 (Rogers et al., 1999), identified in this contrast as well. Among nonbelievers, the activation of ACC has been previously reported when performing tasks that interrogate the individual's own life meaning-system (Inzlicht et al., 2009; Inzlicht and Tullett, 2010), which agrees with the variety of participant experiences reflecting conflicts between their beliefs and their cultural upbringing.

In addition, BA 31 was identified, which includes the posterior cingulate cortex. In previous studies, this region has been associated with attributing social qualities to others using self and third-person perspectives (Newsome et al., 2010), processing emotional elements influencing moral decisions (Mercadillo et al., 2014), and integrating unconscious information from prefrontal to somatosensorial parietal regions to be incorporated 
with the individual's own experiences (Soon et al., 2008). The increased activation of this region might imply moral and mnemonic functions when evaluating The Lord's Prayer as a known cultural text based on the participant's own experience and beliefs, as is manifested in participants' testimonies.

When contrasted with Las Mañanitas, the reading of The Lord's Prayer correlated with BOLD signal in the BA 31 mentioned above, but also with several brain regions participating in sensorial and motor processes too, such as the parietal somatosensory association region in $\mathrm{BA} 5$, premotor cortex in BA 6 , and visual cortex in BA 17. Also, activation was identified in BA 42, which has an important role in auditory processes needed for linguistic comprehension and inner language (Patel et al., 2006; Capek et al., 2010). Interestingly, activation was observed in the declive, located in the cerebellar vermis. Cerebellar activation has been reported while Christian practitioners read The Lord's Prayer (Schjoedt et al., 2009) and has classically been associated with motor functions. It is also related to attention and fine affective expressions in social situations (Sacchetti et al., 2002; Mercadillo et al., 2015). Auditory, motor, and sensory functions inferred for this contrast may be necessary not only for believers but also for nonbelievers when analyzing a complex text in abstract terms, as religion requires.

For the contrast between Las Mañanitas and The Franciscan Prayer, BOLD signal was identified in the temporal pole (BA 38), which is considered as part of the ToM network and related to autobiographical processing and attribution of social-linguistic qualities in others, such as courage or cowardice (Zahn et al., 2007). Activation in BA 38 is reported for Christian practitioners when saying personal silent prayers assuming a kind of interpersonal relationship between the believer and God (Schjoedt et al., 2009).

Thus, reading Las Mañanitas may imply interpersonal processes represented in social celebrations, as is indicated in the participant's transmitted experiences. In support of this idea, other studies have shown that when perceiving human bodies and granting them some type of social knowledge, this region is functionally connected with the inferior frontal cortex in BA 45 (Greven et al., 2016). This region was also observed in this contrast and related to combining logical reasoning and personal beliefs (Tsujii et al., 2010). Activation in BA 38 and BA 45 bounded with BA 47 relates to learning concepts, autobiographical memory, and emotional cognition (Markowitsch et al., 2003). This suggests that reading Las Mañanitas entails personal experiences and differs from The Franciscan Prayer since no personal known attribution is given while reading this last prayer. Since Las Mañanitas implies a culturally learned text involving mnemonic and social-cognitive elements that are also present in The Lord's Prayer, the lack of differences in activations was somewhat expected.

Some limitations must be considered in the interpretation of the results. One limitation implies our experimental design, which did not consider explicitly evaluations of memory. The contrast for The Franciscan Prayer $>$ The Lord's Prayer and The Franciscan Prayer > Las Mañanitas did not indicate brain activation related with mnemonic processes; since The Franciscan prayer constituted an unknown text this result could be expected, but this interpretation is not that simple. Some investigations using fMRI have revealed the activation of the hippocampus, the parahippocampal gyrus, and the perirhinal cortex involving the medial temporal lobe (MTL) when reading novelty texts or sentences. The cognitive functions related to these brain structures involve new memory formation, encodingretrieving processes of contextual and verbal information, and declarative memory about the meaning of the sentences or texts (O'Kane et al., 2005; Poppenk et al., 2008). Nevertheless, the activation of the MTL regions identified by neuroimaging strictly depends of cognitive tasks designed to explicitly evaluate what the participants remember about the text, or to request for a judge or thinking about the text during or immediately after the reading (Diana et al., 2007). In our study, the participants were instructed to carefully read each text, but any response about what they remembered or any kind of judge or thinking they could make about the text were explicitly required during the fMRI session. However, as the participants' testimonies indicate when mentioning sentences of The Franciscan prayer and associations of this text with own experiences and thinking, declarative memory processes attributed to the MTL may be presented during the qualitative interviews after the scanning session. To consider this limitation, and to evaluate the familiarity of The Franciscan prayer and its influence in new memory formation for future studies, an experimental design could include a condition to explicitly evaluate remembered elements or meanings attributed to the text. This design could confirm memory formation congruent with the qualitative testimonies given after the scanning.

The contrast for The Lord's Prayer > Las Mañanitas and for Las Mañanitas > The Lord's Prayer did not reveal brain activation related to mnemonic processes, which confirm that both texts were previously well known by the participants. Nevertheless, the contrast for The Lord's Prayer $>$ The Franciscan Prayer revealed activation in the OFC. As mentioned in some paragraphs above, the cognitive function of this brain region involves autobiographical memory used for relevant individual's decisions and judgments, particularly related to linguistic, emotional, and conceptual elements (Gilbert et al., 2006; Soon et al., 2008; Rameson et al., 2010). In addition, parieto-frontal projections including BA 39 and 40 observed in this contrast, involve working memory to integrate the text with previous individual's experiences (Babiloni et al., 2005; Green et al., 2006). On the other hand, the contrast for Las Mañanitas > The Franciscan Prayer revealed activation of the temporal pole which cognitive function is related to autobiographical experiences associated with social-linguistic attributions in others (Zahn et al., 2007), as it was presented in the testimonies given by the participants during the qualitative enquiry. So, the reading of both The Lord's prayer and Las Mañanitas implies memory or evoked events associated with certain cultural experiences and contexts in which both texts are used in Mexico. Nevertheless, to better elucidate the influence of the familiarity with the texts over the individual's experience and to offer more convincing results about this issue, our experimental design could be complemented with different novel religious and non-religious to be contrasted in future experiments. 
Another limitation in this study is the reduced sample conformed by 20 participants. Currently, it is suggested that the statistical criteria applied for the fMRI analysis are enough to consider as feasible a sample of 20 or less individuals; the inference about neurocognitive processes related with the proper and specific cognitive task is advised as reasonable too. Nevertheless, as a typical statistical approach, fMRI results could be more accurate if larger samples are evaluated and recruited from equivalent selection criteria to reduce both, physiological and cognitive variability. The caution to generalize fMRI data to other samples and to larger populations is a present-day discussion in this field of cognitive neuroscience (Poldrack, 2008, 2012; Chen and Glover, 2015; Poldrack et al., 2017).

On the other hand, the qualitative enquiry applied after the fMRI scanning sessions allowed identify conscious experiences associated with the reading of the three used texts. These data offer a phenomenological approach representing the experience of the individuals and the group (Varela and Shear, 1999; Olivares et al., 2015). Also, this methodology is congruent with recent qualitative approaches to recognize points of view integrating affective, cultural, and spiritual experiences in small samples (Borges et al., 2015). The combined methodological approach used in this study embodies a qualitative description about the cognitive processes and its neural basis of certain aspects of spirituality in atheist people. However, this description may be generalized to understand mental qualities in populations with equivalent socio-demographic characteristics, such as educational level. For greater generalizations and confirmation of our results in other populations, it is necessary to apply similar or equivalent experimental designs in other samples of interest, such as believers or atheist representing different generations, educational levels and approaches, socio-economical levels, variety of religious beliefs, geographical regions, and cultural communities.

Taking into account the limitations exposed above, the present study shows some previously unexplored elements of religiosity and spirituality, which may be useful not only to understand this phenomena but also to think about interdisciplinary ways to study them. Our results agree with reports showing a neural basis of religiosity when nonbelievers are considered, which may elucidate neurocognitive processes related to religiosity but shared with so-called non-religious spiritual and social elements influencing health. Particularly, the semantic and intentional properties of The Franciscan Prayer related to empathy and cooperation may be held by nonbelievers,

\section{REFERENCES}

Alcohólicos Anónimos. (1986). Alcohólicos Anónimos, Trans. 3a Edn. México, DF: Central Mexicana de Servicios Generales de Alcohólicos Anónimos, A.C.

Alcohólicos Anónimos. (2016). Doce pasos y doce tradiciones, Trans. 13th Edn. Ciudad de México: Central Mexicana de Servicios Generales de Alcohólicos Anónimos, A.C.

American Psychological Association. (2002). Ethical principles of psychologist and code of conduct. Am. Psychol. 57, 1060-1073. doi:10.1037/0003066X.57.12.1060

Babiloni, C., Ferretti, A., Del Gratta, C., Carducci, F., Vecchio, F., Romani, G. L., et al. (2005). Human cortical responses during one-bit delayed-response tasks: revealing that atheists make intentional and social attributions just as religious people do. However, believers may turn to God when justifying social support while nonbelievers turn to personal and social elements linked to more general human qualities (Weeks and Lupfer, 2000). Therefore, even though the Franciscan Prayer is a clearly religious text, the evoked thoughts, emotions, and actions may allow for self-reflection and social actions needed for support groups, as indicated in the Franciscan tradition and the AA's proposals.

\section{ETHICS STATEMENT}

Written informed consent was obtained from the participants after the nature of the experiment was explained. The protocol was approved by the Institutional Review Board, Institute of Neurobiology, Universidad Nacional Autónoma de México and was made according to the Ethical Principles that were proposed by the American Psychological Association (2002), the Declaration of Helsinki, and the Ethical Code for Psychologists in Mexico (Sociedad Mexicana de Psicología, 2009).

\section{AUTHOR CONTRIBUTIONS}

RM defined the experimental design, selected the participants, conducted and analyzed the qualitative interviews, applied and analyzed the psychometric evaluation, performed the brain function analysis, and wrote the manuscript; JF-R defined the experimental design, interpreted the behavioral and neurocognitive data, and contributed for the manuscript making; OC participated in the participants recruitment, and performed and analyzed the qualitative interviews; EP obtained the participants' resonance magnetic images; ED-S and JV-M performed the psychometric analysis, interpreted the neurocognitive data, and contributed for the discussion and the manuscript making.

\section{ACKNOWLEDGMENTS}

We thank Paulina Barrios of Acento Traducciones for the manuscript revision and all the volunteers who kindly participated in this study.

\section{FUNDING}

This research was supported by the Unit of Resonance Imaging of the Institute of Neurobiology, Universidad Nacional Autónoma de México.

an fMRI study. Brain Res. Bull. 65, 383-390. doi:10.1016/j.brainresbull.2005. 01.013

Batson, C. D. (2009). “These things called empathy: eight related but distinct phenomena," in The Social Neuroscience of Empathy, eds J. Decety and W. Ickes (Cambridge, MA: MIT Press), 3-15.

Bauer, C. C., Barrios, F. A., and Diaz, J. L. (2014). Subjective somatosensory experiences disclosed by focused attention: cortical-hippocampal-insular and amygdala contributions. PLoS ONE 9:e104721. doi:10.1371/journal. pone. 0104721

Beauregard, M., and Paquette, V. (2006). Neural correlates of a mystical experience in Carmelite nuns. Neurosci. Lett. 405, 186-190. doi:10.1016/j. neulet.2006.06.060 
Bennett, M. R., and Hacker, P. M. (2005). Emotion and cortical-subcortical function: conceptual developments. Prog. Neurobiol. 75, 29-52. doi:10.1016/j. pneurobio.2004.11.002

Bering, J. M. (2002). The existential theory of mind. Rev. Gen. Psychol. 6, 3-24. doi:10.1037/1089-2680.6.1.3

Blastic, M. W. (1997). "Contemplation and compassion: a Franciscan ministerial spirituality," in Franciscan Leadership in Ministry: Foundations in History, Theology and Spirituality, Vol. 7, eds A. Carrozzo, V. Cushing, and K. Himes (St. Bonaventure, NY: Franciscan Institute Publications), 149-177.

Borges, S, Santos, M. B., and Pinheiro, T. G. (2015). Social representations about religion and spirituality. Rev. Bras. Enferm. 68, 524-531. doi:10.1590/0034$7167.2015680406 \mathrm{i}$

Brice, J., and Kourie, C. (2006). Contemplation and compassion: the heart of a Franciscan spirituality of clinical pastoral supervision. J. Pastoral. Care. Counsel. 60, 109-116. doi:10.1177/154230500606000111

Bulbulia, J., and Schjoedt, U. (2013). Toward an evolutionary social neuroscience of religion. Religion Brain Behav. 1, 220-222. doi:10.1080/21535 99X.2011.647851

Caixeta, C. R., Nascimento, L. C., Pedro, I. C., and Rocha, S. M. (2012). Spiritual support for people living with HIV/AIDS: a Brazilian explorative, descriptive study. Nurs. Health. Sci. 14, 514-519. doi:10.1111/j.1442-2018.2012.00705.x

Capek, C. M., Woll, B., MacSweeney, M., Waters, D., McGuire, P. K., David, A. S., et al. (2010). Superior temporal activation as a function of linguistic knowledge: insights from deaf native signers who speechread. Brain Lang. 112, 129-134. doi:10.1016/j.bandl.2009.10.004

Chen, J. E., and Glover, G. H. (2015). Functional magnetic resonance imaging methods. Neuropsychol. Rev. 25, 289-313. doi:10.1007/s11065-015-9294-9

Christensen, J. F., Flexas, A., de Miguel, P., Cela-Conde, C. J., and Munar, E. (2014). Roman Catholic beliefs produce characteristic neural responses to moral dilemmas. Soc. Cogn. Affect. Neurosci. 9, 240-249. doi:10.1093/scan/ nss 121

D'Andrade, R. G. (2001). A cognitivist's view of the units debate in cultural anthropology. Cross Cult. Res. 35, 242-257. doi:10.1177/106939710103500208

Davis, M. H. (1980). A multidimensional approach to individual differences in empathy. Cat. Selected. Docs. Psychol. 10, 1-17.

Decety, J., and Cowell, J. M. (2014). The complex relation between morality and empathy. Trends. Cogn. Sci. 18, 337-339. doi:10.1016/j.tics.2014.04.008

Decety, J., and Yoder, K. J. (2016). Empathy and motivation for justice: cognitive empathy and concern, but not emotional empathy, predict sensitivity to injustice for others. Soc. Neurosci. 11, 1-14. doi:10.1080/17470919.2015.10 29593

Dermatis, H., and Galanter, M. (2016). The role of twelve-step-related spirituality in addiction recovery. J. Relig. Health 55, 510-521. doi:10.1007/s10943015-0019-4

Desbordes, G., Negi, L. T., Pace, T. W., Wallace, B. A., Raison, C. L., and Schwartz, E. L. (2012). Effects of mindful-attention and compassion meditation training on amygdala response to emotional stimuli in an ordinary, non-meditative state. Front. Hum. Neurosci. 6:292. doi:10.3389/fnhum.2012.00292

Diana, R. A., Yonelinas, A. P., and Ranganath, C. (2007). Imaging recollection and familiarity in the medial temporal lobe: a three-component model. Trends. Cogn. Sci. 11, 379-386. doi:10.1016/j.tics.2007.08.001

Díaz-Guerrero, R. (2003). Bajo las garras de la cultura: psicología del mexicano. México, DF: Trillas.

Doré, B. P., Zerubavel, N., and Ochsner, K. N. (2015). "Social cognitive neuroscience: a review of core systems," in APA Handbook of Personality and Social Psychology, eds M. Mikulincer and P. R. Shaver (Washington: American Psychological Association), 693-720.

Echavarría, C. V., Quintero, M., and Vasco, E. (2005). Algunas concepciones de justicia de un grupo de estudiantes universitarios de dos ciudades del país. Revista Científica. 7, 315-332.

Emonds, G., Declerck, C. H., Boone, C., Seurinck, R., and Achten, R. (2014). Establishing cooperation in a mixed-motive social dilemma. An fMRI study investigating the role of social value orientation and dispositional trust. Soc. Neurosci. 9, 10-22. doi:10.1080/17470919.2013.858080

Fernández-Díaz, J. F. (1993). Influencia de la religión en la socialización del mexicano. Master's Thesis in Social Psychology. México, DF: Universidad Nacional Autónoma de México.

Filippi, M., van den Heuvel, M. P., Fornito, A., He, Y., Hulshoff Pol, H. E., Agosta, F., et al. (2013). Assessment of system dysfunction in the brain through
MRI-based connectomics. Lancet Neurol. 12, 1189-1199. doi:10.1016/S1474 4422(13)70144-3

Flagan, T., and Beer, J. S. (2013). Three ways in which midline regions contribute to self-evaluation. Front. Hum. Neurosci. 7:450. doi:10.3389/fnhum. 2013.00450

Ge, J., Gu, X., Ji, M., and Han, S. (2009). Neurocognitive processes of the religious leader in Christians. Hum. Brain Mapp. 30, 4012-4024. doi:10.1002/ hbm. 20825

Geake, J. G., and Hansen, P. C. (2005). Neural correlates of intelligence as revealed by fMRI of fluid analogies. Neuroimage 26, 555-564. doi:10.1016/j. neuroimage.2005.01.035

Gilbert, S. J., Spengler, S., Simons, J. S., Steele, J. D., Lawrie, S. M., Frith, C. D., et al. (2006). Functional specialization within rostral prefrontal cortex (area 10): a meta-analysis. J. Cogn. Neurosci. 18,932-948. doi:10.1162/jocn.2006.18.6.932

González-Blasco, P. (2006). La socialización religiosa de los jóvenes españoles: familia y escuela. Bordón. Revista de Pedagogía 58, 493-518.

Green, A. E., Fugelsang, J. A., Kraemer, D. J., Shamosh, N. A., and Dunbar, K. N. (2006). Frontopolar cortex mediates abstract integration in analogy. Brain Res. 1096, 125-137. doi:10.1016/j.brainres.2006.04.024

Greven, I. M., Downing, P. E., and Ramsey, R. (2016). Linking person perception and person knowledge in the human brain. Soc. Cogn. Affect. Neurosci. 11, 641-651. doi:10.1093/scan/nsv148

Grossoehme, D. H., Cotton, S., Ragsdale, J., Quittner, A. L., McPhail, G., and Seid, M. (2013). "I honestly believe god keeps me healthy so i can take care of my child": parental use of faith related to treatment adherence. J. Health. Care. Chaplain. 19, 66-78. doi:10.1080/08854726.2013.779540

Guassi-Moreira, J. F., Van Bavel, J. J., and Telzer, E. H. (2017). The neural development of 'Us and Them'. Soc. Cogn. Affect. Neurosci. 12, 184-196. doi:10.1093/ scan/nsw134

Han, S., Mao, L., Gu, X., Zhu, Y., Ge, J., and Ma, Y. (2008). Neural consequences of religious belief on self-referential processing. Soc. Neurosci. 3, 1-15. doi:10.1080/17470910701469681

Harris, S., Kaplan, J. T., Curiel, A., Bookheimer, S. Y., Iacoboni, M., and Cohen, M. S. (2009). The neural correlates of religious and nonreligious belief. PLoS ONE 4:e0007272. doi:10.1371/journal.pone.0007272

Inzlicht, M., McGregor, I., Hirsh, J. B., and Nash, K. (2009). Neural markers of religious conviction. Psychol. Sci. 20, 385-392. doi:10.1111/j.1467-9280. 2009.02305.x

Inzlicht, M., and Tullett, A. M. (2010). Reflecting on god: religious primes can reduce neurophysiological response to errors. Psychol. Sci. 21, 1184-1190. doi:10.1177/0956797610375451

Inzlicht, M., Tullett, A. M., and Good, M. (2013). The need to believe: a neuroscience account of religion as a motivated process. Religion Brain Behav. 1, 192-212. doi:10.1080/2153599X.2011.647849

Jack, A. I., Friedman, J. P., Boyatzis, R. E., and Taylor, S. N. (2016). Why do you believe in god? Relationships between religious belief, analytic thinking, mentalizing and moral concern. PLoS ONE 11:e0149989. doi:10.1371/journal. pone.0149989

Jezzard, P., and Ramsey, N. F. (2003). "Functional MRI," in Quantitative MRI of the Brain: Measuring Changes Caused by a Disease, ed. P. Tofts (Chicester: Wiley), 413-454.

Kapogiannis, D., Deshpande, G., Krueger, F., Thornburg, M. P., and Grafman, J. H. (2014). Brain networks shaping religious belief. Brain Connect. 4, 70-79. doi:10.1089/brain.2013.0172

Koenig, H. G. (2009). Research on religion, spirituality, and mental health: a review. Can. J. Psychiatry 54, 283-291. doi:10.1177/070674370905400502

Koski, L., and Paus, T. (2000). Functional connectivity of the anterior cingulate cortex within the human frontal lobe: a brain-mapping meta-analysis. Exp. Brain Res. 133, 55-65. doi:10.1007/s002210000400

Lancaster, J. L., Woldorff, M. G., Parsons, L. M., Liotti, M., Freitas, C. S., Rainey, L., et al. (2000). Automated Talairach atlas labels for functional brain mapping. Hum. Brain Mapp. 10, 120-131. doi:10.1002/1097-0193(200007)10:3<120:: AID-HBM30>3.0.CO;2-8

Lee, D., Pruce, B., and Newman, S. D. (2014). The neural bases of argument structure processing revealed by primed lexical decision. Cortex 57, 198-211. doi:10.1016/j.cortex.2014.04.013

Luo, Q., Perry, C., Peng, D., Jin, Z., Xu, D., Ding, G., et al. (2003). The neural substrate of analogical reasoning: an fMRI study. Brain Res. Cogn. Brain Res. 17, 527-534. doi:10.1016/S0926-6410(03)00167-8 
Markowitsch, H. J., Vandekerckhovel, M. M., Lanfermann, H., and Russ, M. O. (2003). Engagement of lateral and medial prefrontal areas in the ecphory of sad and happy autobiographical memories. Cortex 39, 643-665. doi:10.1016/ S0010-9452(08)70858-X

McConnell, K. M., Pargament, K. I., Ellison, C. G., and Flannelly, K. J. (2006). Examining the links between spiritual struggles and symptoms of psychopathology in a national sample. J. Clin. Psychol. 62, 1469-1484. doi:10.1002/ jclp. 20325

Mercadillo, R. E., Alcauter, S., Fernandez-Ruiz, J., and Barrios, F. A. (2014). Police culture influences the brain function underlying compassion: a gender study. Soc. Neurosci. 10, 135-152. doi:10.1080/17470919.2014.977402

Mercadillo, R. E., and Díaz, J. L. (2013). Neuroscience and ethnography: an interdisciplinary revision and a cognitive proposal based on compassion research in Mexico. Int. J. Psychol. Res. 6, 94-108. doi:10.21500/20112084.723

Mercadillo, R. E., Diaz, J. L., Pasaye, E. H., and Barrios, F. A. (2011). Perception of suffering and compassion experience: Brain gender disparities. Brain Cogn. 76, 5-14. doi:10.1016/j.bandc.2011.03.019

Mercadillo, R. E., Galvez, V., Diaz, R., Paredes, L., Velazquez-Moctezuma, J., Hernandez-Castillo, C. R., et al. (2015). Social and cultural elements associated with neurocognitive dysfunctions in spinocerebellar ataxia type 2 patients. Front. Psychiatry 6:90. doi:10.3389/fpsyt.2015.00090

Mercadillo, R. E., Trujillo, C., Sánchez-Cortazar, J., and Barrios, F. A. (2012). In ADHD patients performing the counting Stroop task: a social neuroscience approach. Psychol. Rep. 111, 652-668. doi:10.2466/15.10.19. PR0.111.5.652-668

Mochizuki, A. A., Sudo, M. M., Kirino, E., and Itoh, K. (2014). Brain activation associated with motor imagery of coordination exercises and social abilities. Eur. J. Sport. Sci. 14, 671-677. doi:10.1080/17461391.2014.893019

Moll, J., de Oliveira-Souza, R., Moll, F. T., Ignacio, F. A., Bramati, I. E., CaparelliDaquer, E. M., et al. (2005). The moral affiliations of disgust: a functional MRI study. Cogn. Behav. Neurol. 18, 68-78. doi:10.1162/jocn.2008.20109

Montero-López, L. M., and Sierra, C. L. (1996). Escala de bienestar espiritual: Un estudio de validación. Vol. VI. Asociación Mexicana de Psicología Social. La Psicología Social en México. 6, 28-33.

Mutschler, I., Reinbold, C., Wankerl, J., Seifritz, E., and Ball, T. (2013). Structural basis of empathy and the domain general region in the anterior insular cortex. Front. Hum. Neurosci. 7:177. doi:10.3389/fnhum.2013.00177

Newsome, M. R., Scheibel, R. S., Hanten, G., Chu, Z., Steinberg, J. L., Hunter, J. V., et al. (2010). Brain activation while thinking about the self from another person's perspective after traumatic brain injury in adolescents. Neuropsychology 24, 139-147. doi:10.1037/a0017432

Norenzayan, A., and Gervais, W. M. (2013). The origins of religious disbelief. Trends. Cogn. Sci. 17, 20-25. doi:10.1016/j.tics.2012.11.006

O'Kane, G., Insler, R. Z., and Wagner, A. D. (2005). Conceptual and perceptual novelty effects in human medial temporal cortex. Hippocampus 15, 326-332. doi:10.1002/hipo.20053

Olivares, F. A., Vargas, E., Fuentes, C., Martinez-Pernia, D., and CanalesJohnson, A. (2015). Neurophenomenology revisited: second-person methods for the study of human consciousness. Front. Psychol. 6:673. doi:10.3389/ fpsyg.2015.00673

Paloutzian, R., and Ellison, C. (1982). "Loneliness, spiritual well-being and the quality of life," in Loneliness: A Sourcebook of Current Theory, Research and Therapy, eds L. A. Peplau and D. Perlman (New York: John Wiley \& Sons), 224-235.

Patel, R. S., Bowman, F. D., and Rilling, J. K. (2006). Determining hierarchical functional networks from auditory stimuli fMRI. Hum. Brain Mapp. 27, 462-470. doi:10.1002/hbm.20245

Pérez-Albéniz, A., de Paúl, J., Etxeberría, J., Paz-Montes, M., and Torres, E. (2003). Adaptación del Interpersonal Reactivity Index (IRI) al Español. Psicothema $15,267-272$.

Poldrack, R. A. (2008). The role of fMRI in cognitive neuroscience: where do we stand? Curr. Opin. Neurobiol. 18, 223-227. doi:10.1016/j.conb.2008.07.006

Poldrack, R. A. (2012). The future of fMRI in cognitive neuroscience. Neuroimage 62, 1216-1220. doi:10.1016/j.neuroimage.2011.08.007

Poldrack, R. A., Baker, C. I., Durnez, J., Gorgolewski, K. J., Matthews, P. M., Munafo, M. R., et al. (2017). Scanning the horizon: towards transparent and reproducible neuroimaging research. Nat. Rev. Neurosci. 18, 115-126. doi:10.1038/nrn.2016.167
Poppenk, J., Walia, G., McIntosh, A. R., Joanisse, M. F., Klein, D., and Köhler, S. (2008). Why is the meaning of a sentence better remembered than its form? An fMRI study on the role of novelty-encoding processes. Hippocampus 18, 909-918. doi:10.1002/hipo.20453

Puchalska-Dabrowska, B. M. (2006). The definition of illness and aspects of patient care in early Franciscan sources. Arch. Hist. Filoz. Med. 69, 1-13.

Raichle, M. E. (2001). Cognitive neuroscience. Bold insights. Nature 412, 128-130. doi: $10.1038 / 35084300$

Rameson, L. T., Satpute, A. B., and Lieberman, M. D. (2010). The neural correlates of implicit and explicit self-relevant processing. Neuroimage 50, 701-708. doi:10.1016/j.neuroimage.2009.12.098

Renoux, C. (2001). La prière pour la paix attribuée à saint François, une énigme à résoudre. Paris: Editions Franciscaines.

Rivera-Ledesma, A., and Montero-López, M. (2014). Ajuste psicolo'gico y vida religiosa en adultos mayores. Univ. Psychol. 13, 15-26. doi:10.11144/Javeriana. UPSY13-3.apvr

Rodríguez, G., and Cruz, K. (2014). Percepción del clima emocional, problemas sociales y confianza institucional en tiempos de violencia. Avances en Psicología Latinoamericana 32, 159-166. doi:10.12804/apl32.1.2014.11

Rogers, R. D., Owen, A. M., Middleton, H. C., Williams, E. J., Pickard, J. D., Sahakian, B. J., et al. (1999). Choosing between small, likely rewards and large, unlikely rewards activates inferior and orbital prefrontal cortex. J. Neurosci. 19, 9029-9038.

Rosselli, M., Ardila, A., and Bernal, B. (2015). Modelo de conectividad de la circunvolucio'n angular en el lenguaje: metaanálisis de neuroimágenes funcionales. Rev. Neurol. 11, 495-503.

Sacchetti, B., Baldi, E., Lorenzini, C. A., and Bucherelli, C. (2002). Cerebellar role in fear-conditioning consolidation. Proc. Natl. Acad. Sci. U S A 99, 8406-8411. doi:10.1073/pnas.112660399

Schjoedt, U., Stodkilde-Jorgensen, H., Geertz, A. W., Lund, T. E., and Roepstorff, A. (2011). The power of charisma - perceived charisma inhibits the frontal executive network of believers in intercessory prayer. Soc. Cogn. Affect. Neurosci. 6, 119-127. doi:10.1093/scan/nsq023

Schjoedt, U., Stodkilde-Jorgensen, H., Geertz, A. W., and Roepstorff, A. (2009). Highly religious participants recruit areas of social cognition in personal prayer. Soc. Cogn. Affect. Neurosci. 4, 199-207. doi:10.1093/scan/nsn050

Schwartz, S., Assal, F., Valenza, N., Seghier, M. L., and Vuilleumier, P. (2005). Illusory persistence of touch after right parietal damage: neural correlates of tactile awareness. Brain 128, 277-290. doi:10.1093/brain/awh347

Shibata, M., Toyomura, A., Itoh, H., and Abe, J. (2010). Neural substrates of irony comprehension: a functional MRI study. Brain Res. 1308, 114-123. doi:10.1016/j.brainres.2009.10.030

Slaby, J., and Stephan, A. (2008). Affective intentionality and self-consciousness. Conscious. Cogn. 17, 506-513. doi:10.1016/j.concog.2008.03.007

Smith, S. M., Jenkinson, M., Woolrich, M. W., Beckmann, C. F., Behrens, T. E., Johansen-Berg, H., et al. (2004). Advances in functional and structural MR image analysis and implementation as FSL. Neuroimage 23(Suppl. 1), S208-S219. doi:10.1016/j.neuroimage.2004.07.051

Sociedad Mexicana de Psicología. (2009). Código Ético del Psicólogo. México, DF: Trillas.

Soon, C. S., Brass, M., Heinze, H. J., and Haynes, J. D. (2008). Unconscious determinants of free decisions in the human brain. Nat. Neurosci. 11, 543-545. doi:10.1038/nn.2112

Stoeckel, C., Gough, P. M., Watkins, K. E., and Devlin, J. T. (2009). Supramarginal gyrus involvement in visual word recognition. Cortex 45, 1091-1096. doi:10.1016/j.cortex.2008.12.004

Tian, X., Zarate, J. M., and Poeppel, D. (2016). Mental imagery of speech implicates two mechanisms of perceptual reactivation. Cortex 77, 1-12. doi:10.1016/j. cortex.2016.01.002

Tinoco, J. (1998). Effect of intergroup differentiation on participation with religious young people. Int. J. Psychol. Relig. 8, 197-204. doi:10.1207/ s15327582ijpr0803_5

Torges, C., Ingersoll-Dayton, B., and Krause, N. (2013). Forgiving and feeling forgiven in late adulthood. Int. J. Aging. Hum. Dev. 76, 29-54. doi:10.2190/ AG.76.1.b

Tsujii, T., Masuda, S., Akiyama, T., and Watanabe, S. (2010). The role of inferior frontal cortex in belief-bias reasoning: an rTMS study. Neuropsychologia 48, 2005-2008. doi:10.1016/j.neuropsychologia.2010.03.021 
van den Heuvel, M. P., and Hulshoff, H. E. (2010). Exploring the brain network: a review on resting-state fMRI functional connectivity. Eur. Neuropsychopharmacol. 20, 519-534. doi:10.1016/j.euroneuro.2010.03.008

Varela, F., and Shear, J. (1999). First person methodologies. J. Conscious. Stud. 6, $1-14$.

Vess, M., Arndt, J., Cox, C. R., Routledge, C., and Goldenberg, J. L. (2009). Exploring the existential function of religion: the effect of religious fundamentalism and mortality salience on faith-based medical refusals. J. Pers. Soc. Psychol. 97, 334-350. doi:10.1037/a0015545

Weeks, M., and Lupfer, M. B. (2000). Religious attributions and proximity of influence: an investigation of direct interventions and distal explanations. J. Sci. Study. Relig. 39, 348-362. doi:10.1111/0021-8294.00029

Worsley, K. J. (2001). "Statistical analysis of activation images," in Functional MRI: An Introduction to Methods, eds P. Jezzard, P. M. Matthews, and S. M. Smith (New York: Oxford University Press), 251-270.
Zahn, R., Moll, J., Krueger, F., Huey, E. D., Garrido, G., and Grafman, J. (2007). Social concepts are represented in the superior anterior temporal cortex. Proc. Natl. Acad. Sci. U S A 104, 6430-6435. doi:10.1073/pnas.0607061104

Conflict of Interest Statement: The authors declare that the research was conducted in the absence of any commercial or financial relationships that could be construed as a potential conflict of interest.

Copyright (C) 2017 Mercadillo, Fernandez-Ruiz, Cadena, Domínguez-Salazar, Pasaye and Velázquez-Moctezuma. This is an open-access article distributed under the terms of the Creative Commons Attribution License (CC BY). The use, distribution or reproduction in other forums is permitted, provided the original author(s) or licensor are credited and that the original publication in this journal is cited, in accordance with accepted academic practice. No use, distribution or reproduction is permitted which does not comply with these terms. 